\title{
12 Harnessing the Power of the Khampa Elites
}

\author{
Political Persuasion and the Consolidation of Communist \\ Party Rule in Gyelthang
}

Dáša Pejchar Mortensen

\begin{abstract}
The fascinating life story of Wangchuk Tempa (1886-1961), a fierce defender of local autonomy in Gyelthang, illustrates how the Chinese Communist Party utilized the power and charisma of local political and religious leaders to consolidate its rule in southern Kham between $195^{\circ}$ and 1958. Wangchuk Tempa's legendary actions reveal that 'collaboration' is too simplistic a concept to explain why some local leaders joined forces with representatives of the Chinese state in response to mounting social and political pressures in the 1950s. Party officials turned to 'political persuasion' to entice recalcitrant Khampa leaders, such as Wangchuk Tempa, to cooperate, and they strategically granted pre-revolutionary local elites positions in the post-1950 government, in order to strengthen nascent Party control in Gyelthang.
\end{abstract}

Keywords: Gyelthang, tusi system, Khampa rebellions, political persuasion, political tourism, land reform

Acknowledgements: The research for this chapter was made possible through a Charlotte W. Newcombe Doctoral Dissertation Fellowship, a Harry Frank Guggenheim Foundation Dissertation Fellowship, a Jacob K. Javits Fellowship, an Esherick-Ye Family Foundation Fellowship, and grants administered by Davidson College's Dean Rusk International Studies Program and the Faculty Study and Research Program. I am very grateful to my interlocutors and colleagues living in Gyelthang for sharing with me their knowledge of Wangchuk Tempa's exploits and legendary reputation. The convenors and participants of the 2016 international conference on 'Territories, Communities, and Exchanges in the Sino-Tibetan Borderlands' provided valuable feedback on an earlier draft of this chapter.

Gros, Stéphane (ed.), Frontier Tibet: Patterns of Change in the Sino-Tibetan Borderlands. Amsterdam, Amsterdam University Press 2019

DOI: $10.5117 / 9789463728713 \_C H 12$ 


\section{Introduction}

Numerous accounts of the early years of Chinese Communist Party (C.C.P.) involvement in Gyelthang mention the exploits of Wangchuk Tempa (18861961), an early-twentieth-century political and military leader in northwest Yunnan Province. ${ }^{1}$ While a few short testimonials written by C.C.P. officials who interacted with Wangchuk Tempa in the early 195 os recall him as a 'bandit leader' and 'anti-revolutionary rebel' who later came to see the error of his ways (Liao 1987 and Sun 1987), Gyelthang residents today often refer to his legendary actions in laudatory and mythic terms. ${ }^{2}$ Wangchuk Tempa's life story illustrates the extent to which certain members of the Tibetan political and religious elite played crucial roles in the C.C.P.'s consolidation of their rule in Gyelthang. A close examination of these local elites' actions reveals that the C.C.P.'s use of 'political tourism' and 'political persuasion work' to control Gyelthang was far more penetrating than the level of political control that could have been achieved through military conquest alone. ${ }^{3}$

Aside from competing monastic powers in the area, not a single unified political authority or hierarchical social organization formed the basis of collective identity and governance in Gyelthang until the Chinese Communist government exerted its control over the region in the mid-1950s. In the late seventeenth century, the desirability of the area led the Fifth Dalai Lama to dispatch troops from the Central Tibetan (Ganden Phodrang) army

1 Gyelthang is located in the easternmost foothills of the Himalaya Mountains in the northwest corner of present-day Yunnan Province in southern Kham. From 1724 until 2001, this area was referred to as Zhongdian in Chinese. In 2001 Zhongdian County was renamed Xianggelila County. Some of the more detailed Chinese-language sources that describe Wangchuk Tempa's resistance to the Chinese Communist government in Gyelthang in the late 1940s and early 1950s include Sulang 1990, Huang 1998, and Gesang 2010.

2 Interviews with Gyelthang residents in July, 2012, October, 2012, and June, 2014. Jamyang Norbu (Norbu 2009) maintains that Gyelthang residents called Wangchuk Tempa by his Tibetan nickname, Aku Lemar, meaning 'Uncle Hairless', since he was bald, whereas Tibetans from other areas called him Wangchuk Tempa. According to the Zhongdian County Gazetteer, villagers in Termarong (Ch. Dongwang) and Ketsak (Ch. Geza) called him Wangchuk Tembu, whereas villagers from Gyelthang and Yangthang (Ch. Xiao Zhongdian) referred to him affectionately as 'Uncle Wangchuk Tempa'. Yangthang is located 40 kilometers south of Gyelthang's administrative centre, which the Qing government named Zhongdian ting after establishing their garrison there in 1724. The Chinese Communist government later renamed this administrative centre Zhongxin zhen. Tibetans in other areas allegedly insulted Wangchuk Tempa by calling him Wangchuk Tempa Lemar, meaning 'Wangchuk Tempa with the Red Forehead' (Zhongdian xianzhi 1997, 909).

3 For an explanation of 'political tourism', see Bulag (2012). For more on 'political persuasion work', see Mullaney $(2010,105)$. 
to support the growing influence of the Geluk school of Buddhism (Tsomu 2015, 22-23). Although the Karma Kagyü monasteries in Gyelthang resisted this Geluk influence, the Fifth Dalai Lama successfully ordered subjects of the Muli king, located just to the southeast of Gyelthang, to unite with Tibetan-Mongolian allied forces and suppress the Kagyü monasteries' armed insurrection (Wang 1995, 89-151). By the end of the seventeenth century, the Ganden Phodrang had converted many important Kagyü monasteries to the Gelukpa tradition, and due to kinship ties between monastic and secular rulers in Gyelthang, the political influence of the Gelukpa monastic institutions soon became closely intertwined with that of the local wealthy secular rulers (Schwieger 2015, 69). However, despite its influence over the monastic institutions in the region, the Ganden Phodrang government never exerted direct political control over Gyelthang in any consistent manner (Schwieger 2011; Holmes-Tagchungdarpa 2015, 348). In 1724, after successive campaigns in the region by the Qing military, the Qing government stationed garrisons in Gyelthang (Ch. Zhongdian), Dechen (Ch. Deqin), and Balung (Ch. Weixi) and formally incorporated these three districts into Yunnan Province (Wang 1995, 108-109, 159, 171). Yet, even after it came under the nominal jurisdiction of Yunnan Province, day-to-day issues of governance were still largely resolved at the local level in Gyelthang. Up until the Chinese Communist Party consolidated its control over the area in the mid-twentieth century, villages in Gyelthang bonded together primarily for the purpose of dealing with external threats and maintaining social cohesion at the local level. ${ }^{4}$ The way that Wangchuk Tempa mediated between different power holders at the local, regional, and state levels vividly demonstrates how savvy local leaders managed to exert a great deal of control in southern Kham during an era of enormous political and social change. ${ }^{5}$

\section{Wangchuk the Rebel}

Lobsang Nima, or Wangchuk Tempa as he was known later in life, was born into a relatively poor household in Termarong (Ch. Dongwang xiang) in

4 Yudru Tsomu (2015, xxviii-xxix) maintains that a similar system of social organization existed in Nyarong in the nineteenth and early twentieth centuries. Also see Mueggler (2001) for interesting parallels amongst the neighbouring Lòlop'ò.

5 For an account of another charismatic and savvy Khampa strongman, see Yudru Tsomu's chapter in this volume on Jagö Topden. See also Pirie and Huber, eds. (2008). 
1886. ${ }^{6}$ At ten years old, Wangchuk Tempa entered the monastic life, and after receiving ten years of monastic training at Ganden Sumtseling Monastery in Gyelthang, he moved to Lhasa to continue his education one of the monastic colleges (kangtsen) in Sera Monastery for one year (Zhongdian xianzhi 1997, 909). He returned to the Termarong monastic college in Sumtseling Monastery in Gyelthang in 1907, and eight years later he became a teacher in that monastic college.

At the time, Gyelthang was frequently targeted by bandits from Chaktreng and Termarong, where villagers formed bands based on kinship ties and frequently engaged in raids on neighbouring towns. ${ }^{7}$ A group of nearly 100 Sumtseling monks were organized in 1916 to defend the monastery against such bandit attacks, and the leaders of the eight monastic colleges appointed Wangchuk Tempa the leader of this bandit defense force (Zhongdian xianzhi 1997, 909; Gesang 2010, 425-426).

In 1919, after the Chinese Nationalist army stationed in Gyelthang (Zhongdian Town) levied a heavier grain tax on Gyelthang residents in order to support their troops in the area, villagers from 300 households in Termarong rebelled (Zhongdian xianzhi 1997, 909). ${ }^{8}$ Wangchuk Tempa and eleven other Sumtseling monks from Termarong returned to Termarong to participate in the uprising, and villagers soon selected Wangchuk to

6 Wangchuk Tempa was born in the present-day village of Zhalujiangzhong Wang Xueding Village, located in Xinlian Administrative Village in Termarong, which is currently part of Xianggelila County in Diqing Tibetan Autonomous Prefecture in Yunnan Province. The previous name for this village was Kenading, meaning 'above the stockade'. According to the Zhongdian County Gazetteer, the local pronunciation of the name of this village closely resembled the word 'Kanading', which in the Gyelthang Tibetan language had the inauspicious meaning of 'Black Mouth'. When Lobsang Nyima travelled to Lhasa as a young man to continue his studies, he consulted with monastic authorities and was told that Kenading residents had long suffered from poverty because they had the misfortune of living in this ill-named village. Lobsang Nyima was therefore advised to change the name of his village to Wangchuk Tempa, meaning 'wealth and power'. From then on, people in his village started referring to him as 'the one from Wangchuk Tempa Village' (Yunnan sheng difangzhi 2002, 452; Zhongdian xianzhi 1997, 909).

7 According to Yudru Tsomu $(2015,20)$, it was conventional in this region for bandits first to compensate the families of bandits who had died or been wounded during raids, and then to divide what was left of the spoils of war amongst the surviving raiders. For more on banditry in Chaktreng, Termarong, and Gyelthang, see Van Spengen (2002, 15-22); Goullart (1955, 91-92); and Wong (2002a, 17-19).

8 Van Spengen $(2002,19)$ claims that in 1922 'Chungtien [Zhongdian] fell to the Tongwa [Dongwang people] from Konkaling [Gongling near Yading]. It had already fallen into the hands of regular Tibetan troops in 1917, but had been handed over again to the Chinese in 1918. The Tongwa drove out the Chinese officials and robbed the Chinese soldiers of their rifles'. In compiling this historical narrative, van Spengen draws on Rock $(1947,251,257)$ and Kingdon Ward $(1923,29)$. 
lead the rebellion (Zhongdian xianzhi 1997, 909; Yunnan sheng difangzhi bianzuan weiyuanhui 2002, 452; Zhongguo renmin zhengzhi 2003, 141). In the aftermath of the Termarong rebellion, Wangchuk Tempa and his rebel troops turned to banditry, and by the mid-1920s he had recruited a well-armed militia of 2500 men on horseback (Zhongdian xianzhi 1997, 910). ${ }^{9}$ This local militia not only protected Gyelthang from roaming bandits and Chinese military incursions, but also led profitable raids on neighbouring towns (van Spengen 2002, 19). Wangchuk Tempa acquired more military, political, and economic influence over the next few years. In 1923, Luo Shuchang, the provincial garrison commander of Balung, travelled to Termarong to meet with Wangchuk Tempa and appointed him the Deputy Commander of the District Defense Force (tuanfang) for Gyelthang, Balung, and Dechen (Zhongdian xianzhi 1997, 909). Wangchuk Tempa set up his government headquarters in Zhongdian Town and used his considerable political and military clout to enforce strict security in the region (Gesang 2010, 426).

Bandit raids from Termarong and Chaktreng continued to plague Lijiang and the Tibetan areas just to the south of Gyelthang, and in 1927 the Zhongdian County Governor appointed Wangchuk Tempa the commander of Zhongdian's monk and layperson militia (sengsu tuanwu zhihui) (Zhongdian xianzhi 1997, 910). Due to Wangchuk Tempa's willingness to ruthlessly suppress all uprisings in the area, his military, political, and economic power base quickly surpassed that of any of the 23 tuguan and county governors in Gyelthang, Balung, or Dechen (Zhongdian Xianzhi 1997, 910). The Nationalist government appointed Kelzang Tsering, a Khampa from Bathang, to be the Commissioner for Guomindang Affairs of Xikang, and in $193^{2}$ the Nationalist government sent him to Bathang to establish a Nationalist Party organization in the region and weaken the influence of the Sichuan warlord Liu Wenhui (Tuttle 2005, 147-150). ${ }^{10}$ Kelzang Tsering joined with local people to launch the 'Khampa rule of Kham' (Kangren zhi Kang) movement from his home town of Bathang, and in 1932 he gave

9 Joseph Rock $(1925,453)$ reports on one battle in 1923, in which 1200 Tibetan 'bandits' crossed the Yangtze River and fought the 'Battle of Peshwe Bridge' within 20 miles of Lijiang, killing many Chinese soldiers. Van Spengen $(2002,19)$ urges us to be cautious about the accuracy of Rock's report, since Rock indicates that almost the entire Chinese army was killed, compared to only one of the reportedly 1200 Tibetan 'bandits' who fought in this battle.

1o Nationalist government officials, Chinese de facto military leaders in Kham (such as Liu Wenhui), and Republican intellectuals (such as Ren Naiqiang) referred to Kham as 'Xikang' well before the province of Xikang was officially established in 1939. Tsomu (2013) and Relyea (this volume) describe many of the competing political discourses regarding the Kham frontier during the Republican era. 
Wangchuk Tempa the power to investigate all incidents of unrest in the southern Kham regions of Gyelthang, Dechen, and Balung and use his local militia to restore peace (Zhongdian xian zhi 1997, 910; Gesang 2010, 428). ${ }^{11}$

\section{Encountering the Communists}

When the Chinese Workers' and Peasants' Red Army passed through northern Yunnan Province in May, 1936, Wangchuk Tempa commanded his militia to attack the bedraggled and half-starved Communist troops. ${ }^{12}$ A total of 160 soldiers and five officers were killed and many more were wounded during armed skirmishes with Wangchuk Tempa's militia during the seventeen days that the Red Army spent gathering supplies or crossing the mountain passes in Gyelthang (Sun 2011). ${ }^{13}$ While many Gyelthang residents joined Wangchuk Tempa's militia in fighting against the Red Army, others appear to have been at least partially won over by the Red Army soldiers' actions, speeches, and musical performances in town. ${ }^{14} \mathrm{~A}$ growing

11 For more on Kelzang Tsering's role in the Guomindang government, the 'Khampa rule of Kham' movement, and the power struggle between Liu Wenhui, the Nationalist government, and Kelzang Tsering in Xikang, see Goldstein et al. (2004, 10-14), Peng (2002, 72), Tuttle (2005, 148-149), and Lawson (2013).

12 As various Communist armies in the south attempted to evade being captured by Nationalist troops, different divisions of the Chinese Workers' and Peasants' Red Army (Zhongguo gongnong hong jun) took part in a series of marches that later came to be known collectively as the 'Long March'. Arguably the best known division of the Red Army is the First Front Army of the Chinese Soviet Republic, which marched from Jiangxi Province to Shaanxi Province between October, 1934 and October, 1935. In Yunnan, the Long March took place much later, as Commanders He Long and Xiao Ke led 18,0oo troops in the Second and Sixth divisions of the Red Army through Gyelthang and into Sichuan Province between 25 April and 9 May 1936. As an important landmark in the history of the Communist Party, the Long March is currently commemorated in the Diqing Red Army Long March Museum in Gyelthang, as well as at other former sites along the Red Army's route. One of the main streets that runs from north to south in Zhongxin Town was named Long March Road (Changzheng lu) in 1982 (Sulang 1990, 108; Diqing zhouzhi 2003, vol. 1, 22). The Second Front Army described the challenges that it faced in securing adequate food provisions in Kham during the Long March in 'Zhongguo gongnong hongjun er fangmian jun zhengzhi bu' (1991). Sperling (1976a) and Liu (2004, 96-98) analyze the major linguistic, political, and logistical obstacles that the Red Army faced in Kham.

13 The Yunnan Provincial Gazetteer reports that over 200 Red Army soldiers and five officers were killed during battles with Wangchuk Tempa's militia in 1936 (Yunnan sheng difangzhi bianzuan weiyuanhui 2002, 452).

14 Some Gyelthang residents joined the Red Army as translators when the army came through town and seven of these translators died in battles just a few days after joining the army. Interview with the director of the Diqing Red Army Long March Museum in Gyelthang in July, 2014. There are also (somewhat questionable) accounts of pregnant Tibetan slaves, who were so impressed 
underground Communist Party (dixia dang zuzhi) gained support among young, well-educated, and relatively wealthy Tibetan and Naxi residents in Gyelthang during the fourteen years between the Red Army's departure from Gyelthang in 1936 and the People's Liberation Army's arrival in $1950 .{ }^{15}$

A small group of Tibetan Communist activists proposed to use Dechen as their base of operations from $1945^{-1946}$, since there were not any permanently stationed Guomindang troops in Dechen at that time. Moreover, the de facto governor of Dechen was Gönpo Tsering (Ch. Hai Zhengtao), a Tibetan Communist Party sympathizer who had joined the government of the short-lived independent 'Böpa People's Republic', or 'Greater Tibetan State' (Ch. Da Xizangguo) set up by the Red Army in Ganzi (Kandzé) in Sichuan Province, when the Red Army crossed through Kham during the Long March (Wangyal 2007, 5; Goldstein et al. 2004, 94; Liu 2004, 95-99). In order to stave off an invasion by the Japanese military, which was in control of nearby Burma in 1945, the Guomindang sent Gönpo Tsering to Dechen with a supply of 300 guns and a mandate to establish a local Tibetan guerilla force to defend the area. Gönpo Tsering soon became the commander of the Dechen military and the governor of Dechen County; Han Chinese residents of Dechen called him 'Commander Hai' (Hai siling) (Deqin xian zhi 1997, 343; Goldstein 2004, 94).

In September, 1946, Gönpo Tsering, Bapa Püntsok Wangyel from Bathang, Ngawang Kesang from Xikang, and He Qichang from Gyelthang secretly established the 'Eastern Tibetan People's Autonomous Alliance' (Böshar gyümi mang rang kyong na tün; Ch. Dongzang renmin zizhi hui) in Yunniang Village, located in Shengping Town in Dechen (Sun 2011). ${ }^{16}$ The Charter of the Eastern Tibetan People's Autonomous Alliance cited Sun Yatsen's Three Principles of the People as its guiding philosophy and announced the alliance members' intentions to improve Khampas' lives by introducing new farming techniques, building roads, and abolishing the corvée tax system. Chinese Communist-style guerrilla warfare tactics would be utilized to overthrow

by the Red Army commanders' speeches about the need to do away with social inequality in Gyelthang that they named their newborn children 'Communist' (Le'an 2003, 84).

15 The biographies of Tashi Tsering and Bapa Phüntsok Wangyel provide useful insights into why some young Tibetans found communism attractive in this early period (Wangyal 2007; Goldstein et al., 1997; Goldstein et al., 2004). On Naxi support for the underground Communist movement in Lijiang in the 1940s, see White $(2002,134)$.

16 He Qichang was a Tibetan merchant who came from a powerful and wealthy family in Gyelthang. His father, He Rongguang, served as the Police Chief of Zhongdian County and the company commander (qianzong) of the defense force in Ketsak during the Republican period until he was assassinated by the monk warlord Ajian from Termarong in 1930 (Feng 2013, 151; Zhuoma 2015, 4). 
local Guomindang-backed warlords and establish a truly autonomous region for Tibetans in southern Kham (Goldstein et al. 2004, 99-100, 319-324). The leaders of this alliance intended to recruit Dechen Middle School students to join their organization and to finance their expanding organization by taking control of the Guomindang tax office in Dechen. However, their plan was foiled when the Guomindang preemptively discovered their intentions and killed Gönpo Tsering. ${ }^{17}$

In the wake of this failed uprising against the Guomindang-backed Chinese warlords in southern Kham, the number of Gyelthangpa in the Communist Party gradually grew in the late 1940s, but the majority of Gyelthang's secular and religious leaders remained wary of joining the underground C.C.P. ${ }^{18}$ Ever since the Guomindang government had appointed Wangchuk Tempa the Vice Governor of Zhongdian County in the early 1940s, it had become increasingly dangerous for revolutionary-minded Gyelthang residents to agitate for local political, social, or economic change. Throughout the 1940s, Wangchuk Tempa continued to consolidate his power by engaging in well-planned attacks on his enemies, including a highly-esteemed lama from his home town of Termarong. In the aftermath of one particularly vengeful attack, during which Wangchuk Tempa's troops looted and burned 72 houses in a village near Ganden Sumtseling Monastery, Ngawang Lobzang Tendzin (1899-1967), the seventeenth reincarnation of the Zangbum Lama of Ganden Sumtseling Monastery in Gyelthang, reportedly became very alarmed. He summoned Wangchuk Tempa to ask him when he intended on turning his wrath against the Rinpoche himself (Zhongdian xian zhi 1997, 911; Wong 2002b, 11).

Wangchuk Tempa allegedly expressed remorse for the hundreds of lives he had taken in battle, and in 1947 he travelled to Lhasa to rededicate himself to

17 The C.C.P. posthumously awarded Gönpo Tsering membership in the Communist Party (Deqin xian zhi 1997, 6; Le'an Wangdui 2009, 17). Püntsok Wangyel subsequently fled and spent the next few months in hiding; he eventually ended up becoming one of the most influential and controversial Tibetan leaders in the Communist Party (Goldstein 2004).

18 Apart from He Qichang, a few other young Gyelthangpa joined the underground Communist Party in Lijiang in 1947 and quickly rose through the ranks of the Party. One such student was Liu Hanxun (1918-1972), the second son of Liu En (1888-1967), a powerful tusi in Gyalthang. As a young man, Liu Hanxun travelled to Lijiang to take the entrance exam for high school. Upon failing the exam, he became a horse caravan (mabang) leader and merchant on the Tea Horse Road (cha ma gu dao) that ran from southern Yunnan, through Gyelthang, and west to Lhasa (Yang 2013). Leather workers in Gyelthang, as well as Nyishar potters, who had become famous for their beautiful black clay pottery, also used the Tea Horse Road trade network to sell their commissioned wares to Tibetan patrons in Lhasa (Interview with Nyishar potter on 26 April 2013). 
Buddhist studies. However, just one year later, he returned back to Gyelthang, since monastic leaders in Lhasa had urged him to defend his home town from Communist aggression after the P.L.A.'s recent military successes in other areas of Kham (Zhongdian xian zhi 1997, 911).

In April 1949, Li Liesan, the leader of the Snow Mountain Society (Xueshanshe), a trade insurance association (baoshangdui) based in Lijiang, invited Wangchuk Tempa's nephew, Wang Qupi, to dinner and appointed him the director of the Gyelthang office of the Snow Mountain Society. ${ }^{19}$ The next month, at the invitation of the Snow Mountain Society, Wangchuk Tempa sent one of his trusted embassaries to Lijiang to meet with He Qichang and inquire about cooperating with the underground Communist Party to expel a bandit gang from southern Kham (Zhongdian xian zhi 1997, 911).

In late August 1949, the Communist Party sent ten members of the Western Yunnan Work Group to meet with Wangchuk Tempa and the monastic leaders of Ganden Sumstenling Monastery and discuss the C.C.P.'s ethnic and religious policies (Zhongdian xian zhi 1997, 911; Song and Tao 1992a, 39). The Party representatives were prepared to write a very glowing report about the progress the Party had made in Tibetan areas of Yunnan, when they were blindsided. On 3 September 1949, as they rode through the south gate of Zhongdian town, accompanied by a security retinue of a dozen members of Gyelthang's City Defense Volunteer Militia (chengfang yiwu dadui) - including founding members of the Gyelthang branch of the underground Communist Party - they were intercepted by Lobsang Wangdü, Wangchuk Tempa's trusted friend and the commander of the Yangthang Civilian Corps (Xiao Zhongdian mintuan dadui).$^{20}$ According to a first-person

19 In the late 1940s, two of the most successful traders in southern Kham were Li Liesan, a wealthy merchant from Lijiang who controlled much of the horse caravan trade in Gyalthang in the 1940s, and the Heqing merchant Bao Pinliang. Li and Bao joined together in 1947 to form a very successful trade insurance association (baoshangdui), called the Snow Mountain Society (Xueshanshe), which expanded its membership base to over 40,00o merchants across Kham and into southern Yunnan Province by the late 1940s. Liu Hanxun and He Qichang worked directly under the command of Li Liesan and engaged in a thriving horse trade caravan business (Feng 2013, 119). Many prominent members of the Snow Mountain Society also joined the underground Communist Party in Heqing and Lijiang in 1948 and 1949.

20 During the late 1940s, wealthy landholders in Southern Kham frequently worked together to fund privately-run Civilian Corps (mintuan dadui) to military defend their regional interests and protect their towns from bandit raids. The leader of the Yangthang Civilian Corps was Lobsang Wangdü, who much like Wangchuk Tempa, was a former monk-turned-brigade leader. In 1927, after the Zhongdian County Governor appointed Wangchuk Tempa the commander of Zhongdian's monk and layperson militia, Wangchuk Tempa turned over the job of defending Yangthang to his trusted friend, Lobsang Wangdü (Zhongguo renmin zhengzhi xieshang huiyi 2005, 9). 
narrative account written by Song Guozhu, one of the commanders of Gyelthang's City Defense Volunteer Militia and the squad leader (bazong) of Gyelthang, Lobsang Wangdü announced that Wangchuk Tempa insisted his Yangthang Civilian Corps should escort the Western Yunnan Work Group members from Gyelthang to Jiangbian to ensure their safe passage. The Gyelthang City Defense Volunteer Militia members were wary of Wangchuk Tempa's intentions, and they refused Lobsang Wangdü's offer three times, but eventually they were persuaded to hand over responsibility for the security of the Western Yunnan Work Group to the Yangthang Civilian Corps (Song and Tao 1992a, 41). Later that afternoon, local bandits launched a surprise raid on the Western Yunnan Work Group, killing six members of the work group, including Li Liesan, and injuring five others (Zhongdian xian zhi 1997, 911). Although Wangchuk Tempa adamantly denied responsibility at the time, he was widely rumoured to have orchestrated the attack (Song and Tao 1992a, 41). ${ }^{21}$

On 20 October 1949, Wangchuk Tempa assembled the chieftains from Gyelthang, Dechen, and Balung, along with the monastic leaders of Sumtseling and the surrounding monasteries, to discuss the region's future. At the meeting, Rinpoche Ngawang Lobzang Tendzin of Ganden Sumtseling Monastery, and Zhao Baohe, the Tibetan commander of Gyelthang's City Defense Volunteer Militia and a relatively new member of the Communist Party, tried to convince Wangchuk Tempa that the P.L.A. was too powerful and that he should try to negotiate rather than fight a losing battle (Le'an 2003, 18). Wangchuk Tempa ignored this advice and organized a number of local militias to engage in a well-coordinated attack on the P.L.A. on 29 October 1949. The attack was successful, and Wangchuk Tempa's coalition militia killed many P.L.A. soldiers and work team members, burned Party offices, and stole valuable P.L.A. property. ${ }^{22}$

One of the C.C.P.'s most strategic moves in governing ethnic minority regions was its United Front policy of incorporating local ethnic leaders into its post-1949 government. From 29 August 1950 until 31 January 1951, the central Chinese government in Beijing dispatched a delegation

21 In a confession he wrote in 1959, which he most likely penned under duress after undergoing a series of interrogations during the Anti-Rightist Campaign, Wangchuk Tempa expressed remorse for having planned this deadly ambush (Wang 1989, 615).

22 According to the Zhongdian County Gazetteer, Wangchuk Tempa met with the tusi and monastic leaders in Gyelthang, Dechen, and Balung, to raise funds and support for a militia to repel the P.L.A. from the region. Many battles took place during the winter of 1949-1950, including one battle in which 330 houses were burned in Judian (Zhongdian xian zhi 1997, 911). 
of anthropologists, linguists, and Party workers to learn more about the social and economic conditions in northern Yunnan Province (Mullaney $2010,8)$. The delegation's 1951 report provided the foundational knowledge necessary to implement its United Front policy designed to win over the support of local elites. ${ }^{23}$ Under this policy, the C.C.P. officials gave Tibetan religious leaders and wealthy traders prominent positions in the Zhongdian government in the early 1950s, while the People's Liberation Army worked to fully secure this frontier region. Some of the founding members of the C.C.P. in Zhongdian were the educated sons and grandsons of wealthy landlords and tusi (native chieftains). ${ }^{24}$ Young Tibetan C.C.P. members utilized the United Front policy to ensure that their own relatives retained their pre1949 political authority in the region. ${ }^{25}$ The C.C.P. hoped to minimize the possibility of resistance in ethnic minority areas where Party control was weak and its ignorance of local customs was potentially dangerous. This policy of cooperation with the 'patriotic upper strata' also enabled the C.C.P. to handle a dire expertise gap, as local elites often served as translators, mediators, or cultural brokers, and were used to smooth relations between the Party and the populace.

According to Communist Party historiography, Gyelthang was officially 'peacefully liberated' (heping jiefang) on 10 May 1950 (Zhongdian xian zhi 1997, 911). Two days later the P.L.A. sent Wangchuk Tempa's good friend, Lobsang Wangdü, who had already been persuaded to work on behalf of the C.C.P., to urge Wangchuk Tempa to negotiate with the new Communist government. Flanked by his personal bodyguards, Wangchuk Tempa met with the P.L.A. General, Liao Yunzhou, and the Zhongdian County Governor, Sun Zhihe, along with Liu En and Nyetsang Tsering Püntsok, two Tibetan native liutenants (tuqianzong) who had begun working with representatives of the underground Communist government the previous year, on the

23 The Visitation Team published their results in July, 1951 in a document titled The Report of Sub-group Two of the Central Visiting Delegation to Investigate the Conditions of the Ethnic Minorities in Yunnan Province. In 1986 the Yunnan Nationalities Publishing House reprinted this document for general circulation; see Yunnan sheng bianji zu 1986. For more on the United Front policy, see Smith (1994, 55); Bulag (2010, 17), and Weiner (2012).

24 For more on the tusi system in Zhongdian, see Qi $(1993,198)$.

25 On 28 August 1949, the first underground Communist Party branch was established inside the town limits of Zhongdian. By the time the P.L.A. arrived in Gyelthang in May, 1950, more than thirty young Tibetan, Naxi, Bai, and Han residents of Gyelthang had joined the Communist Party or the Communist Youth League (Feng 2013, 138, 151; Le'an Wangdui 2009, 17). The Khampa elites that were in power in the 1930s and 1940s in Gyelthang, Termarong, and Nyishar either remained in power or passed their positions of power onto their sons in the 1950 s and early $1960 \mathrm{os}$, until many of them were killed during struggle sessions at the height of the Cultural Revolution. 
Jingkou mountain pass and negotiated his surrender to the P.L.A. ${ }^{26}$ As a sign of good will, Wangchuk Tempa presented General Liao with four yaks and a Tibetan blanket piled high with gold and silver coins. According to General Liao, who published his account of this meeting in Diqing Prefecture's first volume of officially-collected 'Cultural and Historical Materials' (wenshi ziliao), Liao agreed to accept the four yaks and the blanket out of respect for local gift-giving customs, but he turned Wangchuk Tempa's gold and silver over to the P.L.A. finance office (Liao 1987, 13) ${ }^{27}$ General Liao congratulated Wangchuk Tempa on being appointed to the position of Vice-Governor of Zhongdian County, and he tried to persuade Wangchuk Tempa to accept this post, but Wangchuk Tempa was reportedly reticent to do so (Zhongdian xian zhi 1997, 912).

26 All told, between 1948 and 1953, Wangchuk Tempa battled the P.L.A., surrendered, and then fought them again before professing to surrender again, betraying his allegiance to the P.L.A. and the C.C.P. at least four times. Each time, Chinese Communist Party organizers in Gyelthang tried hard to win Wangchuk Tempa over by giving him even more prominent official government posts (Wong 2002, 11). Liu En was born in the Gyelthang town centre in 1888. He was fluent in both Chinese and Tibetan, and in 1904 he became the native second lieutenant (tubazong) of Yangthang. In 1912, when the Yunnan Republican army came through Gyalthang on its westward march, Liu was given the responsibility of provisioning the Republican army with grain. According to Zhongdian County records, Liu carried out his official duties honorably, and he was awarded a medal of distinction by the Republican government. In 1913 he was appointed to be the native lieutenant (tuqianzong) of Nyishar. In 1932 he successfully organized a local Gyelthang militia to defend the town from Chaktreng bandit attacks, and in acknowledgement of his success, the Guomindang government subsequently appointed Liu to be the Governor of Zhongdian County. In 1944 he was appointed to a new post as Vice-Governor of Zhongdian County (Diqing zangzu zizhizhou minzu zongjiao shiwu weiyuanhui, ed. 20o1, 236; Zhongguo renmin zhengzhi xieshang huiyi, ed. 2003, 144-147; Zhongguo renmin zhengzhi xiesheng huiyi, ed. 2005, 32-33). Nyetsang Tsering Püntsok (Ch. name: Qi Yaozu), was born in 1927 in the Gyelthang town centre. He inherited the post of native lieutenant of Nyishar after his father passed away in 1946 (Zhongguo renmin zhengzhi xiesheng huiyi, ed. 2005, 68-70).

27 Starting in the early 1980 s, Political Consultative Conference members in the Diqing Tibetan Autonomous Prefecture in Yunnan Province began to compile carefully edited, detailed accounts of early Communist Party involvement in this area. Nine volumes of testimonies penned by Tibetan, Naxi, Bai, Han, and Hui religious and political leaders in Diqing were published as wenshi ziliao (cultural and historical materials) between 1987 and 2013. Many of these published documents were local Political Consultative Conference (zhengzhi xieshang huiyi) members' recorded recollections of critical moments between 1949 and 1957 when the People's Liberation Army and the Chinese Communist Party faced local armed resistance in Diqing. These accounts all conclude with the ultimate triumph of the Communist Party after P.L.A. commanders and C.C.P. cadres negotiated with landholders, monks, and warlords, and assured them of the Party's benign religious and ethnic policies. For more on the United Front and the political goals of wenshi ziliao production in the reform era, see Mortensen (2017) and Fromm (2019, 110-153). 
It is likely that Wangchuk Tempa surrendered to the P.L.A. in order to buy time to plan a series of well-coordinated militia campaigns, since he organized two more armed rebellions against P.L.A. troops and Communist leaders in the region in late May, 1950, leading to the deaths of many P.L.A. soldiers, work-team members, and self-defense forces. ${ }^{28}$ On 21 May 1951, Wangchuk Tempa supported a rebellion in the ethnically Naxi area of Sanba, located approximately 120 kilometers to the southeast of Termarong, by sending troops, weapons, and supplies, but the rebellion was suppressed by the P.L.A. (Zhongguo renmin zhengzhi xieshang huiyi, ed. 2003, 62). His nephew, Wang Qupi, started another uprising in March, 1952, when he killed six merchants from Zhongxin Town who were travelling through Yangthang under the protection of General Liao (Sulang 1990, 112; Zhongguo renmin zhengzhi xieshang huiyi, ed. 2003, 62). This uprising lasted until Wangchuk Tempa's troops bore the brunt of a particularly lengthy and devastating exchange of fire in Barlungdrong village (Zhongguo renmin zhengzhi xieshang huiyi, ed. 2003, 63; Thondup 1992; McGranahan 2010, $67){ }^{29}$ The injured Wangchuk Tempa fled with his nephew and 60 of his surviving militia members to a mountain cave in Termarong (Zhongdian xian zhi 1997, 912).

In order to persuade Wangchuk Tempa to come out of the mountains, surrender, and join the new C.C.P. government, General Liao asked one of Wangchuk Tempa's former bodyguards, a Tibetan monk from Yangthang, to join Liao in explaining the C.C.P.'s religious policy to Wangchuk Tempa (Song and Tao 1992b, 86). General Liao also requested Liu En and Nyetsang Tsering Püntsok, the two native liutenants who had been working for the Communist government in Gyelthang since 1950, to negotiate again with Wangchuk Tempa. These Tibetan leaders promised Wangchuk Tempa that if he surrendered to the Communists, he would not be harmed or prosecuted, but instead made a member of the Lijiang Special District United

28 For more on the organizational work that the Communist Party did in Gyelthang to support these predominately Tibetan self-defense forces (ziwei dui yuan), which were referred to locally as the hulu dui, and which later became part of the broader national coalition army known as the 'people's militia' (minbing), see Zhongdian xian zhi $(1997,409)$.

29 The extent of local resistance to the People's Liberation Army's advances is on display today in Gyelthang's Memorial Park, where numerous P.L.A. soldiers who were killed during the so-called liberation of Gyelthang have been buried. Located at the entrance to the Old Town at the southern end of Long March Road, Memorial Park has recently been remodelled. It now boasts an impressive bronze statue of a P.L.A. soldier, a colourful mural with inscriptions observing the event in both Tibetan and Chinese, and newly-planted flowers and trees near the tombs of the fallen soldiers. Every year on Tomb Sweeping Day (Qingming jie), teachers bring their pupils to the Memorial Park cemetery and require them to sweep the P.L.A. soldiers' tombs. 
Government Committee (Lijiang zhuanqu lianhe zhengfu weiyuan). In the end, Wangchuk Tempa capitulated and, accompanied by his four most loyal bodyguards, travelled to Zhongdian Town to meet General Liao and other members of the Lijiang-based United Front Department (Zhongdian xian zhi 1997, 912). The C.C.P. cadres' patience and tenacity in repeatedly engaging in prolonged negotiations with Wangchuk Tempa, despite frequent setbacks and betrayals, demonstrates the extent to which the Party was willing to go to entice powerful Khampa elites to join the United Front.

\section{Wangchuk's Adventures as a Political Tourist}

Wangchuk Tempa was initially very wary of the Party's policies and skeptical that the Communists had the Tibetans' best interests in mind, but he attended United Front officials' lectures in Zhongdian and Lijiang about the Party's ethnic minority policies and eventually, in 1953, he agreed to go on a trip to Chongqing. In Chongqing, Wangchuk Tempa encountered Commander He Long for the first time since they last met on the battlefield in 1936 during the Second Red Army's Long March through Yunnan. According to Communist Party wenshiziliao sources, much to Wangchuk Tempa's surprise, Commander He expressed little animosity toward Wangchuk Tempa for his past actions, including his violent attack on Commander He's own caravan in 1936 (Gesang 2010, 443-444). Instead, Commander He assured Wangchuk Tempa that the Party would not prosecute him for his past crimes, maintaining that Wangchuk Tempa had actually assisted the Communist Party by adroitly defending the autonomy of the Gyelthang people. Commander He listed three ways that Wangchuk Tempa had resisted the imposition of Nationalist government policies in Gyelthang: he had opposed the Nationalist government's efforts to conduct land surveys in Gyelthang, prevented the Nationalist army from conscripting Gyelthang residents, and blocked the circulation of Nationalist-government-issued currency in 1948 (Zhongdian xian zhi 1997, 912).

After a lengthy conversation and many cups of tea, Commander He made arrangements for Wangchuk Tempa to attend Party education classes in Chongqing for the duration of the week (Zhongdian xian zhi 1997, 912). The next week a different battalion commander accompanied Wangchuk Tempa to Beijing to attend Party classes. In Beijing he was welcomed by representatives of the United Front Department and the Nationalities Affairs Committee. Over the course of the next few years, Wangchuk Tempa joined United Front Department cadres and other ethnic minority leaders on 
official tours to schools, factories, and farms in Hunan Province, Beijing, and Kunming. The purpose of these tours was to show the former elite class the progress that China was making under a new socialist system. ${ }^{30}$

Travel and sightseeing, or what the anthropologist Uradyn Bulag has termed 'political tourism', played an important role in the Chinese Communist Party's attempt to win over and transform ethnic minority leaders (Bulag 2012, 147-148). After the C.C.P. came to power, Communist leaders made a concerted effort to invite so-called 'representative figures of the upper echelon' - ethnic minority members of the traditionally elite strata who had not joined the Communist Party - to participate in political tourism. The most important quality for selection as an invitee was the person's 'radiating power' (fusheli), which was measured by the number of people that this person could directly or indirectly influence (Bulag 2012, 143). Although the delegates' attitudes toward the Communist Party were investigated ahead of time, hostile attitudes did not necessarily exclude elites from being invited to participate in political tourism. In fact, as Bulag points out, 'the more powerful or hostile they were, the greater the chances of being invited to Beijing' (ibid.). Certain elites, like Wangchuk Tempa, were even permitted to bring their bodyguards.

The rationale for these political tours originated in a proposal that Ren Naiqiang (1894-1989), a Chinese ethnologist specializing in southwestern frontier issues, made to the Sichuan warlord, Liu Wenhui, in 1934. Ren suggested that 'sightseeing' (guanguang) would be one of the most effective ways to promote the assimilation of Tibetans into a newly constituted Chinese nation. He maintained that ethnic minority leaders who had been to China proper and interacted with the Chinese over a long period of time tended to be more politically submissive, whereas those with limited knowledge of China were more arrogant. Ren alleged that, living in isolation, the frontier people were 'like frogs in a well', convinced that the small circle of sky visible above them was actually the entire heavens. When ethnic minority leaders were 'told about the great size of China and the large population of the Han Chinese people by outsiders who had visited Nanjing and Shanghai', Ren explained, 'they roared with laughter, dismissing it as a lie' (Ren 1934, 232). By Ren's reasoning, the frontier people's resistance to integration was not a political request for maintaining a separate polity for themselves; rather it stemmed from their ignorance of Chinese political and economic policies.

30 In an interview with Melvyn Goldstein in 2003, a Khampa recalled how popular these political tours were amongst young Khampas living in Kandzé in the early 1950s (Goldstein $2014,117)$. 
Their alleged belligerence was attributed to geographical isolation, and the only way out of it was for the frontier people to travel to China and personally observe the country's modernity. ${ }^{31}$

Building on Ren's civilizing logic, the United Front Department designed political tours to positively shape minority leaders' impressions of China. Bulag maintains that:

Prior to each visit, minority leaders would be fed with particular lines of information, and after the visit, they would be organized to have a seminar discussion, not to explore issues from different angles, but to achieve a unified understanding or consensus of what they had seen. Should one of them have a different, or rather 'wrong' opinion, he or she would be 'helped' to understand why they were in the wrong. At the end of the tour, minutes would be drafted, which would then be sent to the provincial or prefectural party committee for approval. The minutes were usually filled with lines of how elite visitors were impressed by Chinese hospitality, how advanced Chinese regions were, and most importantly how powerful the Chinese were. [...] The minority visitors would each be given a copy of the minutes and then charged with going back to their villages to make oral reports on what they had seen. (Bulag 2012, 145-146)

Party documents suggest that Wangchuk's tour of inland China may have helped convince him of the power of the Communist government, or at least of the futility of fighting against it (Gesang 2010, 444). A few months after returning back to Gyelthang in 1953, Wangchuk expressed his willingness to work with the leadership of the Communist Party, and later that same year he agreed to serve as the Vice Governor of Zhongdian County under C.C.P. rule.

\section{The Socialist Transformation of Gyelthang}

As the C.C.P. worked to incorporate Gyelthang into their vision for a new 'modern' Chinese Communist nation-state in the early 1950s, the C.C.P. initially adopted a 'gradualist approach’ to implementing socialist reforms,

31 As Yudru Tsomu points out, 'historical analogy was useful for Ren to justify the assimilation of the people of Kham into China', as it suggested that 'frontier peoples are living in an earlier stage of historical development' and 'civilizing them is simply a matter of bringing them forward in time' (Tsomu 2013, 336). 
since Party officials recognized the importance of gaining the support of local Tibetan, Naxi, Bai, and Han residents while they worked to secure administrative control over the region..$^{32}$ The C.C.P. leaders understood that winning the trust and loyalty of the Gyelthang elites would require patience and perseverance during numerous discussions, private meetings, and public speeches.

The C.C.P.'s United Front Department was responsible for using a variety of tactics to co-opt local elites and build a broad consensus among non-Party members and ethnic minority residents for Party-supported programs and goals. One such tactic was political tourism. Another was 'political persuasion work' (zhengzhi shuifu gongzuo), which entailed lengthy meetings between recalcitrant Tibetan leaders and other local elites who had already been won over by the Communists. Treaties were signed and ceremonies were held to mark the success of winning over particular elites. Rather than deposing, imprisoning, or killing these elites, Communist Party officials encouraged them to join the new government's efforts to govern Gyelthang.

However, while many C.C.P. officials who arrived in Gyelthang after $195^{\circ}$ believed that a policy of compromise was crucial to forming good relations with the local elites, they nevertheless remained suspicious of the political loyalties of these elites. ${ }^{33}$ With rare exceptions, the older generation of wealthy and powerful local elites were not invited to join the C.C.P.; they were instead given government positions that corresponded with the Party's assessment of their potential future value. The C.C.P.'s intent was to maintain traditional symbols of power while gradually changing the content that they symbolized. The Party's policy of compromise was never intended to be permanent; it was only meant to be implemented until the Party's position had been consolidated in Gyelthang. As the Party gained support, as young Gyelthang residents completed their training as new C.C.P. cadres, and as recently-arrived Chinese cadres became familiar with the situation in Gyelthang, the Party envisioned having more room to manoeuvre against the will of the local elites.

The early stages of Communist Party consolidation and state making were welcomed by some residents of Gyelthang, as they seemingly represented a new Chinese administration willing to work alongside local leaders and power holders. Other Gyelthang elites remained wary of C.C.P. rule, having

32 Mao and others within the central Party leadership initially supported this national strategy of gradualism in Yi and Tibetan regions of western China (Goldstein 2014, 4-16, 88).

33 For more on the Communist Party Central Visitation Team's concerns in $195^{1}$ about the political loyalties of the former tusi leaders in Zhongdian, see Wang 1987, 18-20. 
learned early on that landlords in neighbouring Jiangbian had been subjected to violent struggle sessions, tortured, and killed. ${ }^{34}$ Tibetan elites feared that if land reform was implemented in Gyelthang, they would also be struggled against and perhaps killed. They knew very well that they would be targeted by the so-called 'democratic reforms' (minzhu gaige) - the version of land reform (tudigaige) deemed appropriate for ethnic minority areas - despite the fact that the C.C.P. leadership had insisted land reform would be introduced only after consultation with local power holders.

In order to assuage the local elites' concerns, the C.C.P. gradually introduced social and political reforms in Gyelthang. Fearing that a strong emphasis on class would alarm the upper social strata, C.C.P. officials appointed Tibetan elites - often the same people who had served as intermediaries under the Guomindang and its allies - to posts in the newly-established C.C.P. government in Gyelthang, where they served both as filters and conduits between the masses and the state. ${ }^{35}$ While there were obvious risks in allowing the secular and religious elites to retain real power in the short term, the long-term benefits of winning over the Tibetan population were so significant that the C.C.P. was willing to make extraordinary concessions. It was a shrewd strategy that traded short-term setbacks (permitting local religious leaders to retain power and the manorial estate system to continue) for the achievement of longer-term national interests (Tibetans' gradual acceptance of political and economic reforms under Chinese rule).

But from the earliest days of the C.C.P. there had been a fierce debate within its ranks about how long to wait before enacting radical reforms in ethnic minority areas. Leftist voices within the Party leadership argued that, since the elite are rarely won over anyway, there was no point in delaying radical reforms, such as land redistribution and class struggle. Since the Central Committee had not provided clear guidelines for determining when conditions were ripe for reforms, provincial leaders initially had latitude to interpret Mao's instructions as they wished (Goldstein, 2014, 93). However, by late 1955 Yunnan provincial leaders found themselves under increasing pressure to evaluate when local conditions would be appropriate for launching land reform in Gyelthang.

34 Wangchuk Tempa wrote a letter to General Liao on 8 May 1951, expressing his concern that landlords had been struggled against in Jiangbian, just to the south of Gyelthang. Representatives who had returned from a meeting with other ethnic minority leaders in Kunming reassured Wangchuk Tempa that they had been told class struggle would not be carried out in Gyelthang (Wang 1994, 166-167).

35 Benno Weiner notes that a similar gradual approach was used in Tsékhok (Zeku County) in Amdo (Weiner 2012, 33-34). 
In a speech to provincial Party secretaries on 31 July 1955, Mao proclaimed that widespread collectivization would provide the surge in agricultural production necessary to meet the targets outlined in the C.C.P.'s first Five Year Plan. Mao's electrifying speech effectively ended the gradualist approach to reforms in most ethnic minority areas and ushered in a nationwide push for partial collectivization known as the 'High Tide' in socialist transformation (Barnett 2014, xxx) $\cdot^{36}$ Provincial leaders were encouraged to begin implementing reforms by December, 1955 , so that they would have enough time to report their concrete achievements at the next meeting of the National People's Congress in Beijing in March-April 1957 (Goldstein 2014, 102).

The C.C.P. embarked on a new strategy in particularly politicallychallenging ethnic minority areas of the country, designed to persuade local religious and secular elites to accept reforms in exchange for maintaining their current standard of living and social status. These reforms were referred to as 'peaceful democratic reforms' (heping minzhu gaige), to distinguish them from the methods that had been used during 'land reform' (tudigaige) in other regions in China, where landlords and wealthy peasants were subjected to humiliating public struggle sessions. ${ }^{37}$ The Chinese Communist Party announced its new policy of 'adjusting land ownership, renegotiating rent, and liberating the slaves' (tiaotian yizu, jiefang nuli) in Diqing Tibetan Autonomous District in late 1955. However, efforts to demonstrate that the Tibetan masses were demanding these reforms and that the Tibetan elites in Zhongdian would therefore welcome them quickly proved to be problematic.

36 It was during this closed-door speech that Mao famously criticized colleagues who favored a more cautious approach by remarking that 'some of our cadres are tottering along like a woman with bound feet, always complaining that others are going too fast'. Mao complained that these colleagues seemed incapable of taking the bold step of increasing the size and number of agricultural cooperatives (Mao 1977, 184).

37 Goldstein $(2014,91-92)$ explains some of the main differences between, peaceful democratic reforms, and the kinds of land reform carried out in other areas of China:

The salient difference was that [peaceful democratic reforms] were to be done without the humiliation, physical beatings, demeaning tasks, and expropriation of wealth and property that characterized reforms done in inland China - that is, without the elite suffering material impoverishment, social degradation, and political isolation. With peaceful reforms, the former elite who did not oppose reforms would have the status of full citizens, and the state would provide them a standard of living equal to what they had before. Moreover, in many cases, they would be given leadership positions in government. The key leverage when pressuring the Tibetan elite to accept reforms, therefore, was that there would be no struggle sessions and that their standard of living would not decline after reforms were implemented. 
The first stage of reform entailed categorizing the local population according to the Chinese Communist Party's class categories. Local leaders and officials were ordered to collect information about every household in the area and then assign each household one of the following class labels: chieftain (tusi), slave owner (nulizhu), serf owner (nongnu zhu), land owner (dizhu), wealthy farmer (funong), middle-class farmer (zhongnong), poor farmer (pinnong), serf (nongnu), or slave (nuli). $\cdot^{8}$ In Gyelthang, as in many other parts of Kham, Tibetan society was far less strictly divided than in Central Tibet. Unlike in Lhasa, there were not any aristocratic families in Gyelthang, and neither were there 'unpure' (Tib. drib) outcast families, such as blacksmiths and corpse cutters. However, there were wealthy landowners, some of whom held hereditary servants, known locally as shenyog, which could be bought and sold by their owners. ${ }^{39}$ In 1955 it was announced that land that belonged to chieftains, owners of slaves or serfs, landowners, and wealthy farmers would be confiscated and either kept as government-controlled communal lands or redistributed to the poorest members of society (Zhongdian xian zhi 1997, 302-306). This announcement set the stage for a series of armed conflicts between the P.L.A. and wealthy Tibetan farmers, landowners, and monks.

$3^{8}$ The Zhongdian County Gazetteer provides statistics on several of the class categories introduced by the C.C.P. officials during this period. It also provides information about the amount of farmland that was transferred from wealthy landowners to the government or poor peasants. Nearly 80 per cent of Zhongdian County's households were affected by the land reform campaigns (Zhongdian xian zhi 1997, 304). According to Gompo Tashi Andrugtsang, a Tibetan trader from Lithang who led the Khampas in the Chushigandru insurgent army, the C.C.P. implemented reforms as early as 1953 in Gyelthang. Andrugtsang likely is referring to the predominately ethnically-Han, Bai, and Naxi area of Jiangbian, located just north of Lijiang, where reforms were carried out a full two years before they were implemented in ethnically Tibetan areas of Gyelthang (Goldstein 2014, 119). In his autobiography, written in exile and published in 1973, Andrugtsang claims that the population of Gyelthang in 1953 was 'divided into five strata and a terror campaign of selective arrests launched by the Chinese. People belonging to the first three strata were either publically humiliated or condemned to the firing squad' (Andrugtsang 1973, 38).

39 Chinese historians have tended to translate the local Tibetan term, shen, as 'slave' (nuli), while taking yog to mean 'servant'. The term nang'zin was used locally as a more general term for servant (Kolås 2008, 42). In an interview the author conducted in Hala Village in April 2013, one 93-year-old Tibetan resident of Nyishar claimed that she spent the first 30 years of her life as a slave working for a wealthy family in a village near Feilai Temple (Feilai si) in Deqin County. She maintained that after the Communist 'liberation' of northern Yunnan Province, she and seven of her siblings were given a document granting their freedom. A great deal of controversy remains regarding the extent and variety of slavery and serfdom in Kham prior to the Chinese Communist Party's involvement in the area (Goldstein 1986, 79-112, Miller 1987, 65-67, Goldstein 1988, 61-65, and Gros 2016). 


\section{The Khampa Rebellions of 1955-1957}

In order to introduce new land reform policies, Chinese Communist cadres accompanied by P.L.A. escorts entered Tibetan villages in the Chaktreng area in February 1954. According to a monk from Chaktreng Sampheling monastery, most people in the villages refused to cooperate with the cadres, and in a few cases, they attacked the cadres and P.L.A. troops. ${ }^{40}$ Tibetan villagers later managed to block the Chinese cadres and P.L.A. troops' access to a brook for fifteen days, cutting off the Chinese camp's sole source of water. After months of fighting in the surrounding areas, by February 1956, thousands of villagers had taken refuge in Chaktreng Sampheling Monastery, living alongside the nearly 3000 resident monks. The P.L.A. sent airplanes to drop leaflets urging the monks and villagers to surrender, and following an intense and lengthy standoff, the P.L.A. sent a military jet to bomb Chaktreng Sampheling Monastery. The monastery was ruined and the Tibetans who survived the attack either surrendered to the P.L.A. or fled overland to Lhasa (Shakya 1999, 140; Goldstein 2014, 236).

Meanwhile, in 1955, the abbot of Ba Chödeling Monastery (Dingningsi) in neighbouring Bathang sent a letter to Ngawang Lobzang Tendzin, the abbot of Ganden Sumtseling Monastery in Gyelthang, asking him to send troops to support this revolt aimed at protecting Tibetan religion in Kham. The abbot of Ba Chödeling Monastery also sent messengers to monastic officials in Lithang and Chaktreng requesting all Khampas to unite against the Chinese. The letter carried by the Bathang messengers stated:

Lingkha shi of $\mathrm{Ba}$ is already engaged in fighting against the Chinese. No matter what the Chinese Communists say, their aim is to occupy Tibet in the name of Ngabo's Seventeen-Point Agreement. Therefore, every Tibetan must unite and fight until even if there are no men left, women will have to take up weapons. If we let China do whatever it wants, Tibetan Buddhism and the Tibetan race will become extinct. Our property will be confiscated. Evil people will be the leaders and good people will be the servants. It is clear that things will happen which have never before happened in this world. Therefore, we must not be deluded by the Chinese deceit, and we must rise up in unison. We must completely forget personal and collected resentments that 
exist between our different areas, and confront together the enemy of our region. (Lobsang 1971, 134) ${ }^{41}$

The letter asked that Tibetan rebels coming through Gyelthang be given necessary supplies. According to Sulang Jiachu, a Tibetan historian of Gyelthang, the letter also stated that Bathang rebels threatened to burn the homes of villagers in Gyelthang who refused to aid the rebels (Sulang 2007, 276). When this letter arrived in Gyelthang, Ngawang Lobzang Tendzin was meeting with Tibetan abbots and Chinese government representatives in the Tibetan Autonomous Region. Before Ngawang Lobzang Tendzin left Gyelthang to take part in this meeting, he supposedly told his assistant at Sumtseling Monastery: 'We are located along the Han-Tibetan border and we are different from other Tibetan districts. We must be prudent and refrain from participating in the southern Kham rebellion' (Sulang 2007, 277)..$^{2}$ As a result, lamas in high positions of authority at Sumtseling Monastery did not initially participate in the early stages of the Khampa uprisings.

In 1956, Wangchuk Tempa received letters from monastic leaders and secular leaders in Lithang, Bathang, and Chaktreng, asking him to lend his support to the Kham rebellion against Chinese rule and the Communist policy of land reform. ${ }^{43}$ According to a former Communist Party official in charge of implementing land reform in Gyelthang, Wangchuk Tempa responded that he had learned a lesson from his failed rebellions of the past and that he thought it best for the monastic leaders in Kham to compromise and submit to Communist rule in the area (Huang 1998, 37). Wangchuk Tempa refused to join the rebels; instead he held meetings with village leaders to persuade them that the Communist Party had their interests at heart. He reportedly claimed that the C.C.P. had treated him fairly, considering all

41 Cited in McGranahan (2010, 87). For the full text of the 'Seventeen-Point Agreement' that Tibetan and Chinese government representatives signed on 23 May 1951, see Shakya (1999, 449-452).

42 The 1955-1956 uprising in Eastern Tibet is often called the 'Southern Kham Unified Rebellion' (kangnan lianhe panluan) by Gyelthang-based historians writing in Chinese. Chinese scholars based elsewhere in China have termed this rebellion the 'Kangding Rebellion', since Kangding was the headquarters of Eastern Tibet.

43 According to published Communist Party histories, armed uprisings against land reform took place in early 1956 in Derong, Chaktreng, Daocheng, Liangshan, Yanbian, Yanyuan, and Muli in Sichuan Province (Zhongguo renmin zhengzhi xieshang huiyi, ed. 2003, 63). Based on an exile Tibetan history of Lithang, along with a 2003 interview he conducted in India with a Lithang villager who was involved in the uprising, Goldstein maintains that Khampa rebels sent letters to Lithang, Bathang, Gyelthang, Chaktreng, Derge, Nyarong, and Horkhok in January-early February, 1956 (Goldstein 2014, 125). 
of the grief he had caused the Party in the past (Gesang 2010, 445). Wangchuk Tempa allegedly declared that the Party never forced him to write a selfcriticism or engage in a 'speak bitterness' (suku) meeting, and he was never made the target of a class struggle session. According to Communist Party accounts, the C.C.P. had a track record of treating cooperative members of the Gyelthang upper-class well, and Wangchuk Tempa purportedly assured the village heads and the monastery representatives that they had nothing to fear (Huang 1998, 37).

It is possible that Wangchuk Tempa felt pressured to serve as a statecommunity intermediary and support land reform after accepting a position as Vice Governor of Zhongdian County under C.C.P. rule in 1953 (Sulang 1990, 113). Wangchuk Tempa's decision to maintain a neutral stance on land reform may also have been influenced by the fact that, having been privy to many internal government briefings, he understood that the Chinese Communist government was capable of easily suppressing any rebellion with armed force, if necessary. Faced with escalating tensions in the Tibetan Autonomous Region and outright armed rebellion in many areas of Kham, the C.C.P. had gradually abandoned the strategy of the nationalities policy in favor of coercion (Smith 1994, 67). In order to carry out 'democratic reforms' in Gyelthang, the C.C.P. organized peasant self-defense forces that would be responsible for taking control of the guns and ammunition taken from the landlords and rich peasants. By 1956, the C.C.P. had provided guns, ammunition, and basic weapon training to more than 2000 villagers in Gyelthang, including local members of the police force, work team members, and a self-defense troop, with the goal of creating a strong local security force to suppress uprisings (Huang 1998, 37). ${ }^{44}$

In November, 1956, the first rebellion took place at Ganden Sumtseling Monastery after monks publically decreed that all Gyelthang residents should 'Oppose the Peaceful Negotiation of Land Reform and Maintain the Tuguan System, Protect People's Rights and Their Freedom to Practice Religion' (Sulang 2007, 277). Sumtseling monks protested on the streets of Zhongdian, carrying banners proclaiming: 'Protect Ethnicity, Protect Religion' (baozu, baojiao). The People's Liberation Army eventually dispelled this rebellion after a lengthy armed stand-off.

On 3 March 1957, one day after the start of the Tibetan New Year, the Diqing Party Committee announced that necessary preparations had been

44 These people's militias expanded rapidly and by 1959, Gyelthang had 12,117 people's militia members, comprising nearly 39 per cent of the entire labour force in the region (Zhongdian xian zhi 1997, 409). 
completed and land redistribution could now begin in Gyelthang. Three days later, a second major uprising commenced. According to a Gyelthang Tibetan historian of C.C.P. history, village leaders, wealthy farmers, and monks in two of the monastic colleges within Sumtseling Monastery organized an armed rebellion and 1525 rebels, including 364 monks, attacked C.C.P. work teams in the area over the next few weeks (Sulang 2007, 278). The Lijiang Prefectural Party Committee consequently sent Wangchuk Tempa, Ngawang Lobzang Tendzin, and another Tibetan representative to order the rebels to hand over their weapons and horses and attend an official meeting to discuss land reform. However, the rebels not only refused to meet, they insulted and swore at the Tibetan leaders representing the Communist government, denouncing them as 'traitors' (Gyelthang Tib.jya ga) (Huang 1998, 35). Any attempt at reconciliation between the C.C.P. and the rebels ceased at this point.

The Lijiang Prefectural Division of the P.L.A. surrounded Sumtseling monastery with their army vehicles and sent their soldiers to fight the monks and villagers who had barricaded themselves inside. The rebels were defeated after a few days of heavy fighting, and after the battle, the Party stationed Tibetan cadres at the monastery to serve as translators for the P.L.A. soldiers guarding the monastery's valuables. These cadres were also responsible for confiscating the more than 100 weapons they found in the monastery (Sulang 2007, 279).

By early autumn, 1957, resistance to land reform in Zhongdian had been fully suppressed, ushering in a marked decline in the region's autonomy, an irony that was compounded by the establishment of the Diqing Tibetan Autonomous Prefecture in September 1957. Out of consideration for their refusal to support the Sumtseling monks' revolts against land reform earlier in the year, Ngawang Lobzang Tendzin was appointed the Governor of Diqing Tibetan Autonomous Prefecture, and Wangchuk Tempa was made the Vice Governor of this newly established autonomous prefecture. In order to crack down on the power of Sumtseling Monastery and to make sure that the monks could not join with villagers to yet again foment unrest, 46 monks at Sumtseling were arrested. Land deeds that had been stored inside of the monastery were destroyed, additional weapons were confiscated, and the majority of the monks residing at the monastery were sent back to their villages or fled to the mountains (Le'an 2009, 83). ${ }^{45}$

45 Interview with a monk at Dokhar monastic college (kangtsen) in Sumtseling Monastery, July 2014. This locally highly respected lama, who fled to India in 1959, was allowed to return to Sumtseling Monastery in 2006 after he signed a document promising the Chinese government that he would refrain from giving tantric initiations in Gyelthang. 
Land reform in Gyelthang not only redistributed land, it also made obsolete previously hegemonic cultural orderings of the local social landscape, since it eliminated the political and economic power of the monks and the other elite members of Gyelthang society. ${ }^{46}$ Party documents from the 1960 s present the Land Reform Campaign as the final blow to local structures of religious and political power. ${ }^{47}$ Like Wangchuk Tempa, most village elites in Gyelthang held onto their power or passed their positions of authority to their sons as C.C.P. influence grew in the area in the 1940s and 1950s, until the old shuka and tusi administrative systems were finally dismantled during land reform. Many of the religious and secular leaders, such as Ngawang Lobzang Tendzin and Liu En, who accepted official positions under the new government in the early 1950s, served as intermediaries and negotiated on behalf of the Communist government right up until they became targets during the Cultural Revolution in late 1966.

The implementation of land reform in Gyelthang overlapped with the national Anti-Rightist Campaign of 1957-1958, and while the C.C.P. work teams implemented land reform between January and September, 1958, Wangchuk Tempa and other senior local officials and formerly wealthy landlords in Gyelthang were taken to Kunming to participate in struggle sessions and undergo 'rectification' (Zhongguo renmin zhengzhi xieshang huiyi 2003, $64) \cdot{ }^{48}$ After one particular struggle session, Wangchuk Tempa expressed his

46 Tsering Shakya supports this claim, maintaining that 'the dissolution of the economic power base of the monasteries was the most significant social and political event in the history of Tibet since the introduction of Buddhism' (Shakya 1999, 254).

47 The timeframe for land reform in Gyelthang closely followed that of Lithang, Bathang, and Chaktreng in the neighbouring Ganzi Autonomous District of Sichuan Province. In Ganzi, reforms for agricultural areas were initially propagandized in January 1956 and by September 1958, 95 per cent of the Tibetan and Yi population of Sichuan was reported to have undergone 'democratic reforms' (Sangye Yeshi, 1958 [1968], 322). See also Goldstein (2014, 233-277) and the documents reprinted in Diqing zangzu zizhizhou gaikuang bianxiezu, ed. (1960).

48 The Anti-Rightist Movement of 1957-1958 ushered in a much more hardline nationality policy that equated 'local nationalism' (difang minzu zhuyi) with anti-Party, anti-socialist opposition. Deng Xiaoping filed a report in 1957 attacking 'reactionary' ethnic minority cadres, who had supported special policies in ethnic minority areas in order to undermine socialist policies in general. Deng argued that:

social education and anti-Rightist struggles among the minorities have the same content as in the Chinese areas, but stress should also be laid on opposition to tendencies of local nationalism. It should be clearly recognized that all those who make use of local nationalist sentiments and the estrangement between nationalities left over from the past in order to divide national unity and undermine the unification of the motherland act contrary to China's Constitution and jeopardize the socialist cause of our country. They are all anti-socialist Rightists (Deng 1957, 41). For more about the C.C.P.'s attack on 'local nationalism' during the Anti-Rightist Campaign, see Smith (1994, 59-6o), Weiner (2015). 
regret for all of the 'anti-Party acts' in which he had previously engaged as a trader, businessman, and warlord in Gyelthang. ${ }^{49} \mathrm{He}$ was permitted to return to Gyelthang once the Rectification Campaign ended, and on 30 June 1961, he allegedly fell ill and passed away at the age of 76 . On 2 July, religious and political ceremonies were held in his honor. The Diqing Prefectural Party and government, Zhongdian County Party and government, the military, and the local schools all participated in the government-affiliated funeral ceremony (Qi and Xiluo 1990, 45). The Yunnan Provincial government also publically displayed their respect for Wangchuk by placing his funeral announcement in the Yunnan Daily newspaper on 9 July 1961 (Sheng minwei 1961).

\section{Conclusion}

Wangchuk Tempa's life experience as a monk, bandit, strongman, antiCommunist resistance fighter, and eventually a government official who worked to implement Chinese Communist Party-state policies in Gyelthang helps complicate the notion of what constitutes 'the Chinese state' in rural ethnic minority areas. In 'Létat, c'est nous, or We Have Met the Oppressor and He Is Us: The Predicament of Minority Cadres in the PRC', Stevan Harrell (2007) explores how China's cadres have often been called upon to play a dual role that involves representing the state to the community and representing the community to the state.

Throughout the history of the People's Republic of China, the ability of cadres to negotiate state-community relations has been crucial to the success of policy implementation. Harrell argues that 'if state-minority relations, or state-community relations in minority areas, were [simply] Han-minority relations, there would be very little to write about' - it would be a 'situation of clear and direct colonial rule' (Harrell 2007, 223). Yet, in the early 1950s, the C.C.P. government brought ethnic minority citizens into the state as cadres at various levels - not only at the brigade or village level, but also 'as salaried government cadres at the [...] township, county, prefectural, and provincial levels of the administration' (ibid.). As state-community intermediaries, influential local leaders like Wangchuk Tempa increasingly found themselves in double-bind situations.

As this chapter has discussed, Communist Party officials in Gyelthang used the dual strategies of 'political tourism' and 'political persuasion 
work' to entice Wangchuk Tempa and other recalcitrant members of the 'pre-liberation elite' to accept their offers to join the new government. In addition, work team members attempted to cultivate a sense of revolutionary consciousness among non-elite residents of Gyelthang. Patient 'thought work' (sixiang gongzuo) was a crucial component of the Communists' efforts in Gyelthang to create a sense of the voluntary and natural participation of the people in land reform and collectivization.

After land reform was implemented in Gyelthang, local residents were required to attend 'speak bitterness' (suku) meetings and produce testimonials ascertaining their consciousness of class-based oppression in the so-called 'old society' and their present 'liberation' in the 'new society'..$^{\circ}$ 'Speak bitterness' testimonials from young, female Tibetan villagers, in particular, were very effective weapons that enabled state cadres to directly attack Gyelthang's Tibetan Buddhist monastic order. These testimonials were public performances designed to radically upend local hierarchies, which had traditionally mandated respect for elder Tibetan men and lamas. Monks who participated in the 1956-1957 rebellion were also forced to take part in these 'speak bitterness' sessions in late 1958. Some willingly admitted that the pre-liberation era was one of bitterness while others, who refused to speak ill of the pre-land-reform era, were sent away to join production brigades in the villages. ${ }^{11}$ The 'speak bitterness' meetings therefore served to create a new form of socialist consciousness while simultaneously transforming the very structure of local society.

By harnessing the power and charisma of local Khampa religious and secular leaders, the C.C.P. was able to consolidate its political control in Gyelthang during the 1950s. Yet, how appropriate or theoretically useful is the concept of 'collaboration' when it comes to explaining why some religious and secular leaders joined forces with representatives of the C.C.P. in the post-1949 period (Barnett 2006)? Can and should the choices, adjustments, and compromises that Tibetans made under Chinese Communist rule be

$5^{0}$ As many scholars have pointed out, these first-person testimonials of the rural masses' experiences of feudal exploitation and then liberation from class oppression were the narrative backbone of the Chinese Communist revolution (Anagnost 1997, Hershatter 2011, Sun 2013, Makley 2005, and 2008).

$5^{1}$ Only 367 monks were permitted to live at the monastery after 1958 . They were required to work on a collectivized production brigade and to elect one representative from each monastic college to serve on a new monastery democratic organizing committee. Under a new C.C.P. policy titled 'Let the Monastery Take Care of Itself' ( yi si yang si) these remaining monks were ordered in $195^{8}$ to prepare uncultivated land for farming, maintain fertile fields year-round, and supply their own food, water, and fuel (Qi and Xiluo 1990, 47; Kolås 20o8, 43). 
viewed as 'collusion?' Attempting to navigate a binary between resistance and collaboration/collusion may not be the most fruitful way forward when it comes to exploring what actually occurred in Gyelthang during the 1950s. As James Leibold reminds us, and as many of the contributors to this volume demonstrate, in the ethnically diverse Sino-Tibetan borderlands, 'political actors operated in a complex, circuitous, and multilayered environment with multiple centers of authority' (Leibold 2005, 196). These flexible political webs of interaction reveal the limitations of using static 'centre-periphery' or 'state-local' models to describe the dynamic and contingent processes that resulted in new forms of political allegiances in Kham in the 1950 .

When underground Communist Party agents first started negotiating with Tibetan elites in Gyelthang in the late 1940s, it is unlikely that many Tibetans suspected that these negotiations would turn into a lengthy and much more intrusive form of Chinese political involvement in Kham. After all, Gyelthang residents had become accustomed to being ruled by whichever military leader, village head, tusi, or Guomindang government representative held power in the area at any given time. The day-to-day struggles that villagers faced were roughly the same regardless of who held the reins of power, so people often got on with their lives, even when doing so meant adjusting to the demands of external powers. This made the fact that they were being governed by Tibetan village heads who reported to the Chinese Communist government as plausible as the fact that they used to be governed by the same elite group of Tibetan leaders who reported to the Guomindang-backed warlords, and prior to that, Qing government officials. Indeed, Gyelthang's religious and secular leaders could not have foreseen in the late 1940s how complicated their lives would quickly become in the decades ahead.

\section{Glossary of Chinese and Tibetan Terms}

Ajian

Axi dukou

Ba Chödeling Monastery

Balung (Tib.)

Bao Pinliang

baoshangdui

baozu baojiao

Bapa Püntsok Wangyel
阿坚

阿喜渡口

(Tib.) 'Ba' chos sde gling, (Ch.) Dingningsi 丁宁寺

'Ba'lung, (Ch.) Weixi 维西

鲍品良

保商队

保族, 保教

(Tib.) 'Ba' pa phun tshogs dbang rgyal, (Ch.) Pingcuo Wangjie 平措汪阶 / Min Zhicheng 闵志成 


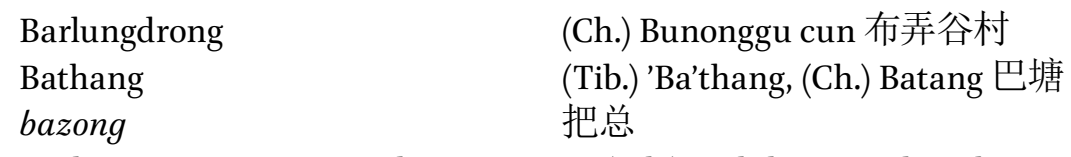

Böshar gyümi mang rang kyong na tün, (Tib.) Bod shar rgyud mi dmangs rang skyong mna' mthun, (Ch.) Dongzang renmin zizhi hui 东藏人 民自治会 / Dongzang renmin zizhi tongmeng jianzhang 东藏人民自治 同盟简章

cha magu dao 茶马古道

Chamdo

Changzheng lu

(Ch.) Changdu 昌都 长征路

Chaktreng

chengfang yiwu dadui

Phyag phreng, (Ch.) Xiangcheng 乡城 城防义务大队

Dali

大理

Dechen

(Tib.) Bde chen, (Ch.) Adunzi / Deqin 阿墩子 / 德钦

difang minzu zhuyi

地方民族主义

Diqing Zangzu zizhizhou

迪庆藏族自治州

dixia dang zuzhi

dizhu

地下党组织

地主

Feilaisi

飞来寺

funong

富农

fushe li

Ganden Phodrang

辐射力

Gelukpa

Dga'ldan pho brang

Gönpo Tsering

Dge lugs pa

(Tib.) Mgon po tshe ring, (Ch.) Gongbu Zeren 恭布泽仁 / Hai Zhengtao 海正 涛 / Hai siling 海司令

gongchan 共产

Gongling

贡岭

guanguang

观光

Gyelthang

(Tib.) Rgyal thang, (Ch.) Da Zhongdian 大中甸

Hai Zhengtao

海正涛

He Long

贺龙

He Qichang

何其昌

He Rongguang

何荣光

heping jiefang

和平解放

hulu dui

护路队

Jiangbian

江边 
Jingkou

Judian

Kanading

Kangnan lianhe panluan

Kangren zhi Kang

kangtsen

Kelzang Tsering

Kenading

Ketsak

Liao Yunzhou

Lijiang zhuanqu lianhe zhengfu weiyuan

Li Liesan

Lithang

Liu En

Liu Hanxun

Lobsang Nyima

Lobsang Wangdü

Long Yun

Luo Shuchang

mabang

minbing

minzhu gaige

Ngawang Kesang

Ngawang Lobzang Tendzin

nongnu

nongnuzhu

nuli

nulizhu

Nyetsang Tsering Püntsok

Nyishar
菁口

巨甸

卡那顶

康南联合叛乱

康人治康

(Tib.) khang tshan

(Tib.) Bskal bzang tshe ring, (Ch.)

Gesang Zeren 格桑泽仁

克那顶

(Tib.) Skad tshag, (Ch.) Geza 格咱

廖云周

丽江专区联合政府委员

李烈三

(Tib.) Li thang, (Ch.) Litang 理塘

刘恩

刘汉勋

(Tib.) Blo bzang nyi ma, (Ch.) Lurong Nima 鲁茸尼玛

(Tib.) Blo bzang dbang 'dus, (Ch.)

Lurong Wangdui 鲁茸汪堆

龙云

罗树昌

马帮

民兵

民主改革

(Tib.) Ngag dbang Skal bzang, (Ch.) Angwang Gesang 昂旺格桑 / Liu Shaoyu 刘绍禹

(Tib.) Ngag dbang Blo bzang Bstan 'dzin, (Ch.) Songmou Angwang Luosang Danzeng Jiacuo 松谋.昂汪洛桑 丹增嘉措

农奴

农奴主

奴隶

奴隶主

(Ch.) Niancang Zeren Pingcuo 念仓 泽仁平措 / Qi Yaozu 七耀祖

(Ch.) Nixi 尼西 


\begin{tabular}{|c|c|}
\hline pinnong & 贫农 \\
\hline qianzong & 千总 \\
\hline Qingming jie & 清明节 \\
\hline Ren Naiqiang & 任乃强 \\
\hline Sanba & 三坝 \\
\hline sengsu tuanwu zhihui & 僧俗团务指挥 \\
\hline Shengping zhen &  \\
\hline shenyog & (Tib.) bran gyog \\
\hline sixiang gongzuo & 思想工作 \\
\hline suku & 诉苦 \\
\hline Sun Zhihe & 孙致和 \\
\hline Termarong & $\begin{array}{l}\text { (Tib.) Gter ma rong, (Ch.) Dongwang } \\
\text { 东旺 }\end{array}$ \\
\hline tiaotian yizu, jiefang nuli & 调田议租, 解放奴隶 \\
\hline tuanfang & 团防 \\
\hline tubazong & 土把总 \\
\hline tudigaige & 土地改革 \\
\hline tuqianzong & 土千总 \\
\hline tusi & 土司 \\
\hline Uncle Wangchuk Tempa & $\begin{array}{l}\text { (Tib.) Dbang phyug Bstan-pa akhu, } \\
\text { (Ch.) Wang Xueding Agou 汪学鼎阿沟 }\end{array}$ \\
\hline Wang Qupi & $\begin{array}{l}\text { 汪曲批 / Wang Chuipi汪吹匹 / Wang } \\
\text { Xuepi 汪学批 }\end{array}$ \\
\hline Wangchuk Tempa & (Tib.) Dbang phyug Bstan-pa, (Ch.) \\
\hline & $\begin{array}{l}\text { Wang Xueding 汪学鼎/ Wang Xued- } \\
\text { ingba 汪学鼎巴 }\end{array}$ \\
\hline Wangchuk Tempa Lemar & $\begin{array}{l}\text { (Ch.) Wang Xueding Liemu 汪学鼎 } \\
\text { 列木 }\end{array}$ \\
\hline Xianggelila xian & 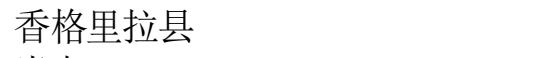 \\
\hline Xiao Ke & 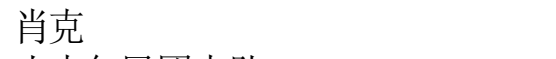 \\
\hline Xiao Zhongdian mintuan dadui & 小中甸民团大队 \\
\hline Xinlian xingzhengcun & 新联行政村 \\
\hline Xueshanshe & 雪山社 \\
\hline Yading & 亚丁 \\
\hline Yangthang & $\begin{array}{l}\text { (Tib.) Yang thang, (Ch.) Xiao Zhong- } \\
\text { dian 小中甸 }\end{array}$ \\
\hline yi siyang si & 以寺养寺 \\
\hline Yunnan & 云南 \\
\hline Yunniang cun & 酝酿村 \\
\hline Zhalujiangzhong Wang Xueding cun & 扎路江仲汪学顶村 \\
\hline
\end{tabular}


Zhao Baohe

zhengzhi shuifugongzuo

zhengzhixieshang huiyi

Zhongdian

Zhongdian mintuan

Zhongguo gongnong hong jun

zhongnong

Zhongxin zhen

ziwei duiyuan

赵宝鹤
政治说服工作
政治协商会议
中甸
中甸民团
中国工农红军
中农
中心镇
自卫队员

赵宝鹤

政治说服工作

政治协商会议

中甸

中触勾

中国工农红军

中农

自卫队员

\section{References}

Anagnost, Ann. 1997. National Past-Times: Narrative, Representation and Power in China. Durham: Duke University Press.

Andrugtsang, Gompo Tashi. 1973. Four Rivers, Six Ranges: Reminiscences of the Resistance Movement in Tibet. Dharamsala, India: Information and Publicity Office of H.H. The Dalai Lama.

Barnett, Robert. 2006. 'Beyond the Collaborator-Martyr Model: Strategies of Compliance, Opportunism, and Opposition within Tibet'. In Contemporary Tibet: Politics, Development, and Society in a Disputed Region, edited by Barry Sautman and June Teufel Dreyer, 25-66. Armonk, N.Y.: M.E. Sharpe.

Barnett, Robert. 2014. 'Introduction: A Note on Context and Significance'. In My Tibetan Childhood: When Ice Shattered Stone, written by Naktsang Nulo and translated by Angus Cargill and Sonam Lhamo, xv-li. Durham: Duke University Press.

Bstan-pa-rgyal-mtshan. 1985. Rgyal than் yul lun dgon gnas dan் bcas pa'i byun ba mdo tsam brjod pa blo gsal mgul pa mdzes pa'i rgyan (A History of the Gyelthang Gompa Monastic Complex and its Environs). Dharamsala, H.P., India: Rgyal-than Bya-'thab, Ṅag-dban் Thabs-mkhas.

Bulag, Uradyn. 2010. Collaborative Nationalism: The Politics of Friendship on China's Mongolian Frontier. Lanham: Rowman \& Littlefield.

Bulag, Uradyn. 2012. 'Seeing Like a Minority: Political Tourism and the Struggle for Recognition in China'. Journal of Current Chinese Affairs 41 (4): 133-158.

Bulag, Uradyn. 2012a. 'Good Han, Bad Han: The Moral Parameters of Ethnopolitics in China'. In Critical Han Studies: The History, Representation, and Identity of China's Majority, edited by Thomas Mullaney, James Leibold, Stéphane Gros, and Eric Vanden Bussche, 92-109. Berkeley: University of California Press.

Deng, Xiaoping 邓小平. 1957. 'On Minorities'. In Report on the Rectification Campaign, 41. Beijing: Foreign Languages Press. 
Deqin xian zhi bianzuan weiyuanhui 德钦县志编纂委员会 (Deqin County Gazetteer Compilation Committee), ed. 1997. Deqin xian zhi 德钦县志 (Deqin County Gazetteer). Kunming: Yunnan minzu chubanshe.

Diqing zangzu zizhizhou gaikuang bianxiezu 迪庆藏族自治州概况编写组 (Diqing Tibetan Autonomous Prefecture Survey Composition Group), ed. 1960. Yunnan Sheng Diqing Zangzu Zizhizhou Gaikuang 云南省迪庆藏族自 治州概况 (A Survey of Diqing Tibetan Autonomous Prefecture in Yunnan Province). Lijiang.

Diqing zangzu zizhizhou minzu zongjiao shiwu weiyuanhui 迪庆藏族自治州 民族宗教事务委员会 (Diqing Tibetan Autonomous Prefecture Nationalities Religious Affairs Committee), ed. 2001. Diqing Zangzu zizhizhou minzu zhi 迪 庆藏族自治州民族志 (Diqing Tibetan Autonomous Prefecture Nationalities Gazetteer). Kunming: Shenzhen huiyuan caise yinshua youxian gongsi.

Diqing zhouzhi bianzuan weiyuanhui迪庆州志编纂委员会 (Diqing Prefecture Gazetteer Compilation Committee), ed. 2003. Diqing zangzu zizhizhouzhi迪 庆藏族自治州志 (Diqing Tibetan Autonomous Prefecture Gazetteer), 2 vols. Kunming: Yunnan minzu chubanshe.

Dreyfus, Georges. 2003. The Sound of Two Hands Clapping: The Education of a Tibetan Buddhist Monk. Berkeley: University of California Press.

Epstein, Lawrence. 2002. 'Introduction'. In Khams pa Histories: Visions of People, Place, and Authority, edited by Lawrence Epstein, 1-5. Leiden: Brill.

Faure, David and Ho Ts'ui-P'ing, eds. 2013. Chieftains into Ancestors: Imperial Expansion and Indigenous Society in Southwest China. Vancouver: University of British Columbia Press.

Feng, Ruzhang 冯如璋. 2013. Feng Ruzhang wenji 冯如璋文集 (An Anthology of Feng Ruzhang's Scholarship). Beijing: Zhongguo minzu sheying yishu chubanshe. Fromm, Martin. 2019. Borderland Memories: Searching for Historical Identity in Post-Mao China. Cambridge: Cambridge University Press.

Gesang, Qiren 格桑棋仁. 2010. ‘Wang Xueding qi ren qi shi 汪学鼎其人其事’ (A Biographical Sketch of Wangchuk Tempa). In Diqing wenshiziliao, diba ji 迪庆 文史资料, 第八辑 (Cultural and Historical Materials from Diqing), vol. 8, edited by Diqing zangzu zizhizhou zhengxie wenshi ziliao weiyuanhui 迪庆藏族自 治州政协文史资料委员会 (The Cultural and Historical Materials Committee of the Chinese People's Political Consultative Conference of Diqing Tibetan Autonomous Prefecture), 423-446. Kunming: Yunnan minzu yinshuachang.

Goldstein, Melvyn. 1986. 'Reexamining Choice, Dependency and Command in the Tibetan Social System: “Tax Appendages” and Other Landless Serfs'. The Tibet Journal 11 (4): 79-112.

Goldstein, Melvyn. 1988. 'On the Nature of Tibetan Peasantry: A Rejoinder'. The Tibet Journal 13 (1): 61-65. 
Goldstein, Melyvn. 2014. A History of Modern Tibet, vol. 3: The Storm Clouds Descend, 1955-1957. Berkeley: University of California Press.

Goldstein, Melvyn, William Siebenschuh, and Tashi Tsering. 1997. The Struggle for Modern Tibet: The Autobiography of Tashi Tsering. Armonk, New York: M. E. Sharpe.

Goldstein, Melyvn, Dawei Sherap, and William Siebenschuh. 2004. A Tibetan Revolutionary: The Political Life and Times of Bapa Phüntso Wangye. Berkeley: University of California Press.

Goullart, Peter. 1955. Forgotten Kingdom. London: John Murray.

Gros, Stéphane. 2016. 'Tricks of the Trade: Debt and Imposed Sovereignty in Southernmost Kham in the Nineteenth to Twentieth Centuries'. Cross-Currents: East Asian History and Culture Review 5 (2): 378-407.

Harrell, Stevan. 2007. 'L'état, c'est nous, or We Have Met the Oppressor and He Is Us: The Predicament of Minority Cadres in the PRC'. In The Chinese State at the Borders, edited by Diana Lary, 221-239. Vancouver: University of British Columbia Press.

Herman, John. 1993. National Integration and Regional Hegemony: The Political and Cultural Dynamics of Qing State Expansion, 1650-1750. PhD Dissertation, University of Washington.

Herman, John. 1997. 'Empire in the Southwest: Early Qing reforms to the Native Chieftain System'. The Journal of Asian Studies 56 (1): 47-74.

Hershatter, Gail. 2011. The Gender of Memory: Rural Women and China's Collective Past. Berkeley: University of California Press.

Holmes-Tagchungdarpa, Amy. 2015. 'Depicting Life in the Twentieth-Century Sino-Tibetan Borderlands: Local Histories and Modernities in the Career and Photography of Zhuang Xueben (1909-1984)'. In China's Encounters on the South and Southwest: Reforging the Fiery Frontier over Two Millennia, edited by James Anderson and John Whitmore, 339-369. Leiden: Brill.

Huang He 黄河. 1998. 'Zhongdian xian de minzhu gaige 中甸县的民主改革' (Democratic Reforms in Zhongdian County). In Diqing zhou wenshiziliao xuanji, di liu ji 迪庆州文史资料选辑, 第六辑 (An Anthology of Cultural and Historical Materials from Diqing Prefecture), vol. 6, edited by Diqing zangzu zizhizhou zhengxie wenshi ziliao weiyuanhui 迪庆藏族自治州政协文史资料委员会 (The Chinese People's Political Consultative Committee of Diqing Tibetan Autonomous Prefecture, The Cultural and Historical Materials Committee), 34-42. Kunming: Xizhan caiyinchang.

Huber, Toni. 2011. 'Pushing South: Tibetan Economic and Political Activities in the Far Eastern Himalaya, ca. 1900-1950'. In Buddhist Himalaya: Studies in Religion, History and Culture. Proceedings of the Golden Jubilee Conference of the Namgyal Institute of Tibetology, Gangtok, 2008, vol. 1: Tibet and the Himalaya, edited by 
Alex McKay and Anna Balikci-Denjongpa, 259-276. Gangtok: Namgyal Institute of Tibetology.

Kingdon Ward, Francis. 1923. Mystery Rivers of Tibet. London: Seeley Service \& Company.

Kolås, Åshild. 2008. Tourism and Tibetan Culture in Transition: A Place Called Shangrila. New York: Routledge.

Lawson, Joseph. 2013. 'Warlord Colonialism: State Fragmentation and Chinese Rule in Kham, 1911-1949'. The Journal of Asian Studies 72 (2): 299-318.

Le'an Wangdui 勒安旺堆. 2003. Maoniu suiyue 牦牛岁月 (The Yak Years). Kunming: Yunnan renmin chubanshe.

Le'an Wangdui 勒安旺堆. 2009. Dangdai Yunnan zangzujianshi 当代云南藏族简 史 (A Concise Contemporary History of Tibetans in Yunnan). Kunming: Yunnan renmin chubanshe.

Leibold, James. 2005. 'Un-Mapping Republican China's Tibetan Frontier: Politics, Warlordism and Ethnicity along the Kham/Xikang Borderland'. The Chinese Historical Review 12 (2): 167-201.

Liao Yunzhou 廖运周. 1987. 'Zai Zhongdian xian de rizi 在中甸县的日子' (My Days in Zhongdian County). In Diqing zhou wenshi ziliao xuanji, diyiji 迪庆 州文史资料选辑. 第一辑 (An Anthology of Cultural and Historical Materials from Diqing Prefecture), vol. 1, edited by Zhongguo renmin zhengzhi xieshang huiyi, Yunnan sheng Diqing zangzu zizhizhou weiyuanhui, wenshi ziliao yanjiu weiyuanhui 中国人民政治协商会议, 云南省迪庆藏族自治州委员会, 文史资料研究委员会 (Chinese People's Political Consultative Committee, The Committee of Diqing Precture in Yunnan Province, The Cultural and Historical Materials Research Committee), 9-16. Kunming: Yunnan minzu yinshua chang.

Lin, Hsiao-Ting. 2006. Tibet and Nationalist China's Frontier: Intrigues and Ethnopolitics, 1928-49. Vancouver: University of British Columbia Press.

Liu, Xiaoyuan. 2004. Frontier Passages: Ethnopolitics and the Rise ofChinese Communism, 1921-1945. Stanford: Stanford University Press.

Lobsang, Gyaltsen. 1971. 'Ba' kyi lo rgyus (History of Kham Ba-pa). Dehra Dun: Nyingmapa Lamah Press.

Makley, Charlene. 2005. “Speaking Bitterness": Autobiography, History, and Mnemonic Politics on the Sino-Tibetan Frontier'. Comparative Studies in Society and History 47 (1): 40-78.

Makley, Charlene. 2008. 'The Politics of Memory: Gender, Autobiography and Maoist Violence in Amdo'. In Conflict and Social Order in Tibet and Inner Asia, edited by Fernandia Pirie and Tony Huber, 113-133. Leiden: Brill.

Manning, Kimberley. 2007. 'Communes, Canteens, and Crèches: The Gendered Politics of Remembering the Great Leap Forward'. In Re-envisioning the Chinese 
Revolution: The Politics and Poetics of Collective Memories in Reform China, edited by Ching Kwan Lee and Guobin Yang, 93-118. Stanford: Stanford University Press. Mao, Zedong. 1977. 'On the Cooperative Transformation of Agriculture'. In Selected Works of Mao Tsetung, vol. 5, 184-207. Beijing: Foreign Languages Press.

McGranahan, Carole. 2010. Arrested Histories: Tibet, the CIA, and Memories of a Forgotten War. Durham: Duke University Press.

Miller, Beatrice. 1987. 'A Response to Goldstein's “Reexamining Choice, Dependency and Command in the Tibetan Social System"'. The Tibet Journal 12 (2): 65-67.

Mortensen, Dáša Pejchar. 2017. 'Wenshi Ziliao Narratives of Anti-Communist Resistance in Northwest Yunnan'. Unpublished paper presented at the Association for Asian Studies Conference.

Mueggler, Erik. 2001. The Age of Wild Ghosts: Memory, Violence, and Place in Southwest China. Berkeley: University of California Press.

Mullaney, Thomas. 2010. Coming to Terms with the Nation: Ethnic Classification in Modern China. Berkeley: University of California Press.

Norbu, Jamyang. 2009. 'March Winds'. URL: http://www.jamyangnorbu.com/ blog/2009/03/o6/march-winds/. (Accessed on 3 March 2014)

Peng, Wenbin. 2002. 'Frontier Process, Provincial Politics and Movements for Khampa Autonomy during the Republican Period'. In Khams pa Histories: Visions of People, Place and Authority, edited by Lawrence Epstein, 57-84. Leiden: Brill.

Pirie, Fernanda and Toni Huber, eds. 2008. Conflict and Social Order in Tibet and Inner Asia. Leiden: Brill.

Qi Jiguang 祁继光. 1993. 'Diqing tuisi shihua 迪庆土司史话' (The History of Tusi in Diqing). In Fengjian nongnu zhidu zai diqing de fumie 封建农奴制度在迪 庆的覆灭 (The Destruction of the Feudal Slave System in Diqing), edited by Zhonggong Diqing zhouwei dangshi zhengji yanjiu shibian 中共迪庆州委党 史征集研究室编 (The C.C.P. Diqing Prefecture Committee on Party History Research Group), 198-206. Dali: Dali zhou dianzi yinshuachang.

Qi Yaozu 七耀祖 and Xiluo Jiachu 西洛嘉初. 1990. 'Zhongdian Gadan Songzanlin (Guihuasi) Zhilüe 中甸嘎丹松赞林 (归化寺) 志略' (Historical Synopsis of Zhongdian's Ganden Sumtseling (Guihua) Monastery). In Diqing zhou wenshi ziliao xuanji, di san ji 迪庆州文史资料选辑. 第三辑 (An Anthology of Cultural and Historical Materials from Diqing Prefecture), vol. 3, edited by Zhongguo renmin zhengzhi xieshang huiyi, Yunnan sheng Diqing zangzu zizhizhou weiyuanhui, wenshi ziliao yanjiu weiyuanhui 中国人民政治协商会议, 云南省迪庆藏族自治 州委员会, 文史资料研究委员会 (Chinese People's Political Consultative Committee, The Committee of Diqing Precture in Yunnan Province, The Cultural and Historical Materials Research Committee), 17-56. Kunming:Xizhan caiyinchang. Ren Naiqiang 任乃强. 1934. Xikang tujing: minsu pian 西康图经: 民俗篇 (Illustrated Record of Xikang: Volume of Folklore). Nanjing: Xin yaxiya xuehui. 
Reylea, Scott. 2010. Gazing at the Tibetan Plateau: Sovereignty and Chinese State Expansion in the Early Twentieth Century. PhD Dissertation, University of Chicago. Rock, Joseph. 1925. 'The Land of the Yellow Lama'. The National Geographic Magazine 47 (4): 447-491.

Rock, Joseph. 1947. The Ancient Na-khi Kingdom, vol. 1. Cambridge: Harvard University Press.

Sangye Yeshi (Ch. Sangji Yuexi 桑吉悦希 / Tian Bao 天宝). 1968 'Plant Red Flags in Every Corner of the Tibetan and Yi Regions of Szechuan'. (6 September 1958. In Minzu Tuanjie 民族团结 [Nationalities Unite] 9). Reprinted in Tibet 1950-1967, edited by Nai-min Ling, 321-324. Hong Kong: Union Research Institute.

Schwieger, Peter. 2011. 'The Long Arm of the Fifth Dalai Lama: Influence and Power of the Fifth Dalai Lama in Southeast Tibet'. In Buddhist Himalaya: Studies in Religion, History and Culture. Proceedings of the Golden Jubilee Conference of the Namgyal Institute of Tibetology, Gangtok, 2008, vol. 1: Tibet and the Himalaya, edited by Alex McKay and Anna Balikci-Denjongpa, 239-257. Gangtok: Namgyal Institute of Tibetology.

Schwieger, Peter. 2015. The Dalai Lama and the Emperor of China: A Political History of the Tibetan Institution of Reincarnation. New York: Columbia University Press.

Shakya, Tsering. 1999. The Dragon in the Land of Snows: A History of Modern Tibet since 1947. London: Pimlico.

'Sheng minwei fuzhuren Wang Xueding xiansheng bingshi 省民委副主任汪学鼎 先生病逝' (Wang Xueding, Vice Chair of the Provincial People's Committee, Dies from Illness). Yunnan Ribao 云南日报 (Yunnan Daily). 9 July 1961.

Smith, Warren. 1994. 'The Nationalities Policy of the Chinese Communist Party and the Socialist Transformation of Tibet'. In Resistance and Reform in Tibet, edited by Robert Barnett, 51-75. Bloomington: Indiana University Press.

Song Guozhu 松国柱 (interviewee) and Tao Yuhua 陶玉华 (transcriber). 1992a. 'Jingkou shijian fasheng qianhou 菁口事件发生前后' (The Occurrence of the Jingkou Incident). In Zhongdian wenshi ziliao xuanji 中甸文史资料选辑 (An Anthology of Literary and Historical Materials from Zhongdian), edited by Zhongguo renmin zhengzhi xieshang huiyi, Yunnan sheng Zhongdian xian weiyuanhui wenshi ziliao weiyuanhui 中国人民政治协商会议, 云南省中 甸县委员会, 文史资料委员会 (China People's Political Conference, Yunnan Province Zhongdian County Committee, Literary and Historical Materials Committee), 39-42 (unpublished internally-circulated volume).

Song Guozhu 松国柱 (interviewee) and Tao Yuhua 陶玉华 (transcriber). 1992b. 'Shuofu Wang Xueding xia shan touxiang de jingguo 说服汪学鼎下山投降的 经过' (The Process of Persuading Wangchuk Tempa to Come Down from the Mountains and Surrender). In Zhongdian wenshiziliao xuanji 中甸文史资料选 辑 (An Anthology of Literary and Historical Materials from Zhongdian), edited 
by Zhongguo renmin zhengzhi xieshang huiyi, Yunnan sheng Zhongdian xian weiyuanhui wenshi ziliao weiyuanhui 中国人民政治协商会议, 云南省中甸县 委员会, 文史资料委员会 (China People's Political Conference, Yunnan Province Zhongdian County Committee, Literary and Historical Materials Committee), 83-88 (unpublished internally-circulated volume).

Sperling, Elliot. 1976. 'The Chinese Venture in K'am, 1904-1911, and the Role of Chao Erh-feng'. The Tibet Journal 1 (2): 10-36.

Sperling, Elliot. 1976a. 'Red Army's First Encounters with Tibet: Experiences on the Long March'. Tibetan Review 11 (10): 11-18.

Sulang Jiachu 苏朗甲楚. 1990. 'Wang Xueding Zhuanji 汪学鼎传记' (A Biography of Wang Xueding). In Diqing zhou wenshiziliao xuanji, disan ji 迪庆州文史资料 选辑. 第三辑 (An Anthology of Cultural and Historical Materials from Diqing Prefecture), vol. 3, edited by Zhongguo renmin zhengzhi xieshang huiyi, Yunnan sheng Diqing zangzu zizhizhou weiyuanhui, wenshi ziliao yanjiu weiyuanhui 中 国人民政治协商会议, 云南省迪庆藏族自治州委员会, 文史资料研究委员会 (Chinese People's Political Consultative Committee, The Committee of Diqing Precture in Yunnan Province, The Cultural and Historical Materials Research Committee), 105-114. Kunming: Xizhan caiyinchang.

Sulang Jiachu 苏朗甲楚. 2007. SulangJiachu Zangxue wenji 苏朗甲楚藏学文集 (An Anthology of Sulang Jiachu's Tibetan Studies Scholarship). Kunming: Yunnan minzu chubanshe.

Sun, Bintao 孙涁涛. 2011. 'Diqing difang dang shi zhuyao licheng 迪庆地方党史 主要历程' (The Principal Course of Party History in Diqing). Xianggelilawang, 21 June. URL: http://www.xgll.com.cn/xwzx/2011-06/21/content_51608_3.htm. (Accessed on 5 February 2018)

Sun, Feiyu. 2013. Social Suffering and Political Confession: Suku in Modern China. London: World Scientific Publishing Company.

Sun, Zhihe 孙致和. 1987. 'Heping jiefang Zhongdian jingguo: huiyi 1950 nian 和平解 放中甸经过: 回忆一九五O年' (The Process of Peacefully Liberating Zhongdian: Recalling 1950). In Diqing zhou wenshi ziliao xuanji, di yi ji 迪庆州文史资料选 辑. 第一辑 (An Anthology of Cultural and Historical Materials from Diqing Prefecture), vol. 1, edited by Zhongguo renmin zhengzhi xieshang huiyi, Yunnan sheng Diqing zangzu zizhizhou weiyuanhui, wenshi ziliao yanjiu weiyuanhui 中 国人民政治协商会议, 云南省迪庆藏族自治州委员会, 文史资料研究委员会 (Chinese People's Political Consultative Committee, The Committee of Diqing Tibetan Autonomous Prefecture in Yunnan Province, The Cultural and Historical Materials Research Committee), 25-34. Kunming: Yunnan minzu yinshua chang. Thondup, Kargyal. 1992. Mdo khams cha phreng kyi lo rgyus gser gyi snye ma (The Golden Grain of Dokham Chaktreng's History). Dharmasala: Library of Tibetan Works and Archives. 
Took, Jennifer. 2005. A Native Chieftaincy in Southwest China: Franchising a Tai Chieftaincy under the Tusi System of Late Imperial China. Leiden: Brill.

Tsomu, Yudru. 2006. Local Aspirations and National Constraints: A Case Study of Nyarong Gonpo Namgyel and His Rise to Power in Kham (1836-1865). PhD Dissertation, Harvard University.

Tsomu, Yudru. 2013. 'Taming the Khampas: The Republican Construction of Eastern Tibet'. Modern China 39 (3): 319-344.

Tsomu, Yudru. 2015. The Rise of Gönpo Namgyel in Kham: The Blind Warrior of Nyarong. Lanham, MD: Lexington Books.

Tuttle, Gray. 2005. Tibetan Buddhists in the Making of Modern China. New York: Columbia University Press.

Unger, Jonathan. 1993. 'Introduction'. In Using the Past to Serve the Present: Historiography and Politics in Contemporary China, edited by Jonathan Unger, 1-8. Armonk: M. E. Sharpe.

Van Spengen, Wim. 2002. 'Frontier History of Southern Kham: Banditry and War in the Multi-Ethnic Fringe Lands of Chatring, Mili, and Gyethang, 1890-1940'. In Khams pa Histories: Visions of People, Place and Authority, edited by Lawrence Epstein, 7-29. Leiden: Brill.

Wang Hengjie 王恒杰. 1995. Diqing Zangzu shehui shi 迪庆藏族社会史 (The History of Tibetan Society in Diqing). Beijing: Zhongguo zangxue chubanshe. Wang Lianfang 王连芳. 1987. 'Zhongyang fangwentuan dao Zhongdian fangwen de nanwang huiyi 中央访问团到中甸访问的难忘回忆' (The Unforgettable Memory of the Central Visitation Team's Visit to Zhongdian). In Diqing zhou wenshiziliao xuanji, di yi ji 迪庆州文史资料选辑, 第一辑 (An Anthology of Cultural and Historical Materials from Diqing Prefecture), vol. 1, edited by Zhongguo renmin zhengzhi xieshang huiyi, Yunnan sheng Diqing zangzu zizhizhou weiyuanhui, wenshi ziliao yanjiu weiyuanhui中国人民政治协商会议, 云南省迪庆藏族自 治州委员会, 文史资料研究委员会 (Chinese People's Political Consultative Committee, The Committee of Diqing Tibetan Autonomous Prefecture in Yunnan Province, The Cultural and Historical Materials Research Committee), 17-24. Kunming: Yunnan minzu yinshua chang.

Wang Xueding 汪学鼎. 1989. 'Wang Xueding xuexi zongjie (jiechao) 汪学鼎学习总结 (节抄)' (A Summary of Wangchuk Tempa's Lessons [condensed transcription]). In Zhongguo gongchandang Dian xigongwei Dian xibei diwei shiliao xuanbian 中 国共产党滇西工委滇西北地委史料选编 (An Anthology of Historical Materials from the Chinese Communist Party's West Yunnan Working Committee and Northwest Yunnan Prefectural Party Committee), edited by Zhonggong Dali Lijiang Baoshan Nujiang Diqing Dehong dizhouwei dangshi bangongshi 中 共大理丽江保山怒江迪庆德宏地州委党史办公室 (The C.C.P. Dali, Lijiang, 
Baoshan, Nujiang, Diqing, and Dehong Districts' and Prefectures' Committee, The C.C.P. Party History Office), 615-616. Dehong: Dehong minzu chubanshe. Wang Xueding 汪学鼎. 1994. 'Wang Xueding xie gei Liao shizhang de xin 汪学 鼎写给廖师长的信’ (The Letter that Wangchuk Tempa wrote General Liao). In Diqing zhou wenshi ziliao xuanji, diwu ji 迪庆州文史资料选辑. 第五辑 (An Anthology of Cultural and Historical Materials from Diqing Prefecture), vol. 5, edited by Zhongguo renmin zhengzhi xieshang huiyi, Yunnan sheng Diqing zangzu zizhizhou weiyuanhui, wenshi ziliao yanjiu weiyuanhui 中国 人民政治协商会议, 云南省迪庆藏族自治州委员会, 文史资料研究委员会 (Chinese People's Political Consultative Committee, The Committee of Diqing Tibetan Autonomous Prefecture in Yunnan Province, The Cultural and Historical Materials Research Committee), 166-167. Dali zhou: dianzi yinshua chang. Wangyal, Baba Phuntsok. 2007. Witness to Tibet's History. Translated by Tenzin Losel, Jane Perkins, Bhuchung Sonam, and Tenzin Tsundue. New Delhi: Paljor Publications.

Weiner, Benno. 2012. The Chinese Revolution on the Tibetan Frontier: State Building, National Integration and Socialist Transformation, Zeku (Tsékhok) County, 19531958. PhD Dissertation, Columbia University.

Weiner, Benno. 2015. 'A Last Hurrah for the United Front: Pastoral Collectivization, Retrenchment and Rebellion on the Amdo (Qinghai) Grasslands, 19561958'. Unpublished paper presented at the Association for Asian Studies Conference.

White, Sydney. 2002. 'Town and Village Naxi Identities in the Lijiang Basin'. In China offCenter: Mapping the Margins of the Middle Kingdom, edited by Susan Blum and Lionel Jensen, 131-147. Honolulu: University of Hawai'i Press.

Wong, How Man. 2002a. 'A Teacher in Bandit Country'. China Explorers 4 (3): 17-19. Wong, How Man. 2002b. 'Treachery with Honour'. China Explorers 4 (3): 10-11.

Yang, Fuquan. 2013. 'The Ancient Tea and Horse Caravan Road: The "Silk Road" of Southwest China'. The Silk Road Foundation Newsletter. URL: http://www. silkroadfoundation.org/newsletter/2004vol2num1/tea.htm. (Accessed on 31 March, 2019).

Yunnan sheng bianji zu 云南省编辑组 (The Editing Division of Yunnan Province), ed. 1986. Zhongyang fangwen tuan di er fentuan Yunnan minzu qingkuang huiji 中央访问团第二分团云南民族情况汇集 (上) (The Report of the Second Central Visiting Delegation to Investigate the Conditions of the Ethnic Minorities in Yunnan Province), vol. 1. Kunming: Yunnan minzu chubanshe.

Yunnan sheng difangzhi bianzuan weiyuanhui 云南省地方志编纂委员会(Yunnan Province Gazetteer Compilation Committee). 2002. 'Wang Xueding 汪学鼎'. In Yunnan sheng zhi 云南省志 (Yunnan Province Gazetteer), edited by Yunnan 
sheng difangzhi bianzuan weiyuanhui 云南省地方志编纂委员会 (Yunnan Province Gazetteer Compilation Committee), 452-454. Kunming: Yunnan renmin chubanshe.

Zhongdian xian zhi bianzuan weiyuanhui 中甸县志编纂委员会 (Zhongdian County Gazetteer Compilation Committee), ed. 1997. Zhongdian xian zhi 中 甸县志 (Zhongdian County Gazetteer). Kunming: Yunnan minzu chubanshe.

'Zhongguo gongnong hongjun er fangmian jun zhengzhi bu guanyu er liu juntuan changzheng de zhengzhi gongzuo zongjie baogao (zhailu) 中国工农红军二方 面军政治部关于二六军团长征的整治工作总结报告(摘录)' (Final Report by the Political Department of the Second Front Army of the Chinese Workers' and Peasants Red Army on the Second and Sixth Army Groups' Political Work During the Long March, 19 December 1936 [Excerpts])'. 1991. In Minzu Wenti Wenxian Huibian 民族问题文献汇编 (Collection of Documents on the Nationality Question), edited by Zhongguo gongchandang zhongyang tongyizhan gongzuo bu 中国共产党中央统一战工作部 (United Front Department of the Central Committee of the Chinese Communist Party), 436-440. Beijing: Zhonggong Zhongyang Dangxiao Chubanshe.

Zhongguo renmin zhengzhi xieshang huiyi, Yunnan sheng Diqing zangzu zizhizhou weiyuanhui, wenshi ziliao yanjiu weiyuanhui 中国人民政治协商会议, 云南 省迪庆藏族自治州委员会, 文史资料研究委员会 (Chinese People's Political Consultative Committee, The Committee of Diqing Tibetan Autonomous Prefecturein Yunnan Province, The Cultural and Historical Data Research Committee), ed. 2005. Diqing zhou wenshiziliao xuanji, di qi ji 迪庆州文史资料选辑, 第七辑 (An Anthology of Cultural and Historical Materials from Diqing Prefecture), vol. 7. Kunming: Yunnan yafeng san he yinwu jingmao you xian gongsi.

Zhongguo renmin zhengzhi xieshang huiyi, Yunnan sheng Zhongdian xian weiyuanhui 中国人民政治协商会议,云南省中甸县委员会 (The Chinese People's Political Consultative Conference, Yunnan Province Zhongdian County Committee), ed. 2003. Zhongdian xian zhengxiezhi 中甸县政协志 (The Gazetteer of the Chinese People's Political Consultative Conference of Zhongdian County). Dali: Yunnan sheng Diqing zhou wenhua xinwen chuban zhunyin zheng.

Zhongguo renmin zhengzhi xieshang huiyi, Yunnan sheng Zhongdian xian weiyuanhui wenshi ziliao weiyuanhui 中国人民政治协商会议, 云南省中 甸县委员会, 文史资料委员会 (The Chinese People's Political Consultative Conference, Yunnan Province Zhongdian County Committee, Literary and Historical Materials Committee), ed. 1992. Zhongdian wenshi ziliao xuanji 中 甸文史资料选辑 (An Anthology of Literary and Historical Materials from Zhongdian) (unpublished internally-circulated volume).

Zhuoma Qinglin 卓玛青林. 2015. 'Yeye de gushi 爷爷的故事' (Grandfather's Story). Diqing Ribao 迪庆日报 (The Diqing Daily). 2 February: 4. 
About the Author

DÁša PejChar Mortensen is Assistant Professor of History at Davidson College, U.S.A. Her research focuses on ethnic politics, memory, tourism, and the construction of historical narratives in Kham under Chinese Communist rule. She is currently writing a book on the history of Gyelthang in the Mao and post-Mao periods. 